Article

\title{
Twenty-First Century Streamflow and Climate Change in Forest Catchments of the Central Appalachian Mountains Region, US
}

\author{
Brandi Gaertner ${ }^{1}$, Rodrigo Fernandez ${ }^{2}$ and Nicolas Zegre ${ }^{2, *}$ \\ 1 Environmental Science Department, Alderson Broaddus University, 101 College Hill Drive, Philippi, \\ WV 26416, USA; gaertnerba@ab.edu \\ 2 Forestry \& Natural Resources, West Virginia University, 334 Percival Hall, Morgantown, WV 26506, USA; \\ rodrigofernrey@gmail.com \\ * Correspondence: nicolas.zegre@mail.wvu.edu; Tel.: +1-304-293-0049
}

Received: 30 November 2019; Accepted: 3 February 2020; Published: 8 February 2020

\begin{abstract}
Forested catchments are critical sources of freshwater used by society, but anthropogenic climate change can alter the amount of precipitation partitioned into streamflow and evapotranspiration, threatening their role as reliable fresh water sources. One such region in the eastern US is the heavily forested central Appalachian Mountains region that provides fresh water to local and downstream metropolitan areas. Despite the hydrological importance of this region, the sensitivity of forested catchments to climate change and the implications for long-term water balance partitioning are largely unknown. We used long-term historic (1950-2004) and future (2005-2099) ensemble climate and water balance data and a simple energy-water balance model to quantify streamflow sensitivity and project future streamflow changes for 29 forested catchments under two future Relative Concentration Pathways. We found that streamflow is expected to increase under the low-emission pathway and decrease under the high-emission pathway. Furthermore, despite the greater sensitivity of streamflow to precipitation, larger increases in atmospheric demand offset increases in precipitation-induced streamflow, resulting in moderate changes in long-term water availability in the future. Catchment-scale results are summarized across basins and the region to provide water managers and decision makers with information about climate change at scales relevant to decision making.
\end{abstract}

Keywords: climate change; Appalachian Mountains; streamflow sensitivity; water security; water balance partitioning; Budyko

\section{Introduction}

Forested headwater catchments play a critical role in provisioning freshwater to humanity [1-3], but anthropogenic climate change can alter the amount of precipitation (P) partitioned into streamflow $(\mathrm{Q})$, evapotranspiration (E), and storage [4]. Changes in $\mathrm{Q}$ from headwater catchments is of particular concern given the importance of mountain regions in generating fresh water $[5,6]$, which is used by society for drinking and water-intensive production [7-9]. One such headwaters area in the eastern US is the central Appalachian Mountains region (Figure 1). This region provides water to local metropolitan areas including Pittsburgh, Pennsylvania; Charlotte, North Carolina; and Memphis, Tennessee and to downstream cities such as Washington, DC; Cincinnati, Ohio; Louisville, Kentucky; Atlanta, Georgia; and New Orleans, Louisiana [10]. Given the hydrological importance of this region, gaining an insight into the potential impacts of anthropogenic climate change on future $Q$ is critical for developing policies and practices that enhance water security throughout the region [11,12]. 


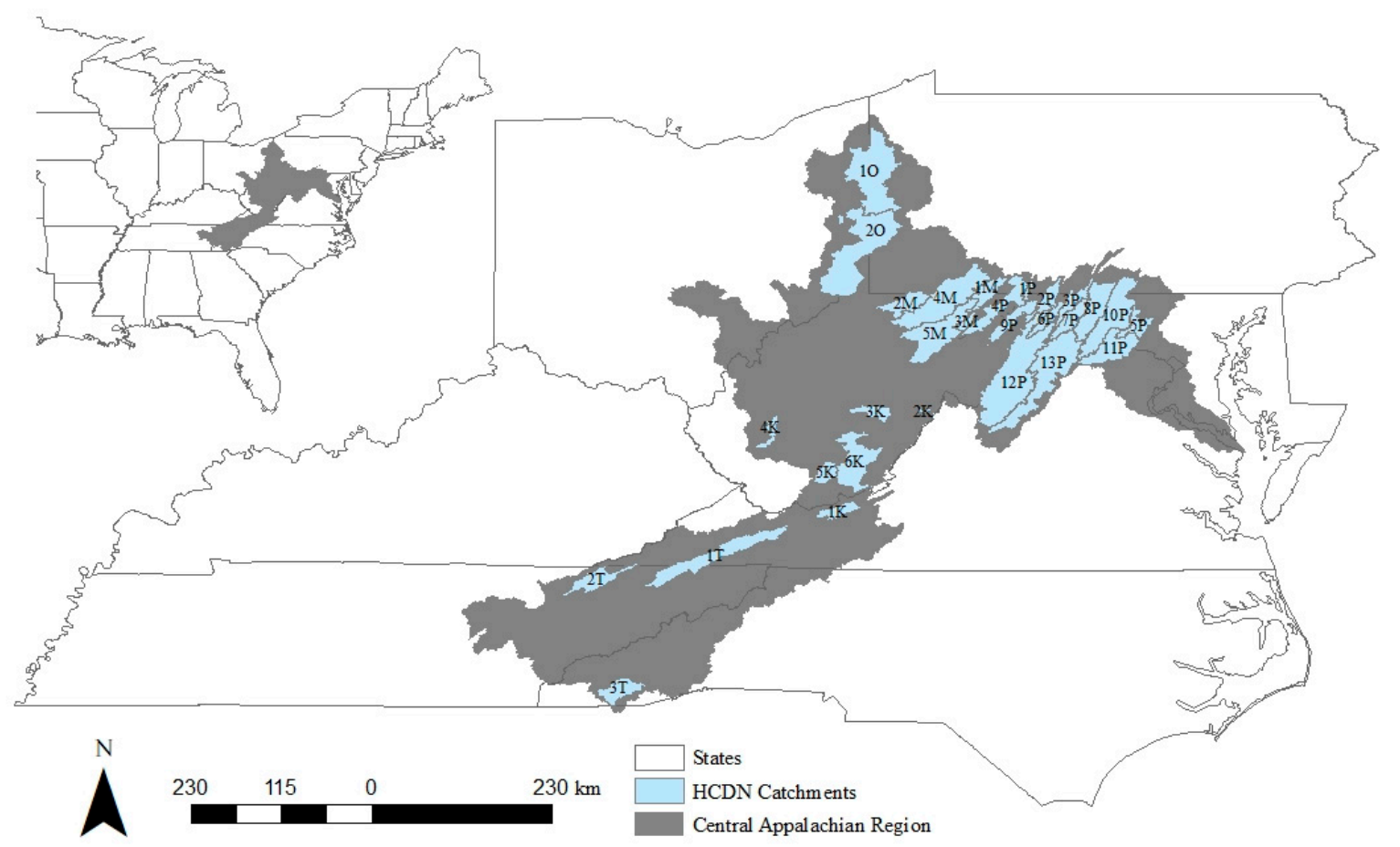

Figure 1. Location map of the U.S. Geological Survey Hydro-Climatic Data Network (HCDN) catchments studied in the central Appalachian Mountains region.

Water availability at the land surface is the result of the balance between atmospheric water demand [12-14], described here as potential evapotranspiration (PET) and P. Atmospheric water demand is driven primarily by solar radiation, which supplies the energy required to vaporize liquid water $[15,16]$. The ratio between PET and $\mathrm{P}$, called the aridity index (AI), describes how much $\mathrm{P}$ is partitioned and returned back to the atmosphere [17-19]. AI is a first-order hydro-climatological control since it describes the absolute amount of water that can be lost to evaporation.

Over the last several decades, this region has become warmer and wetter [20,21], theoretically consistent with water cycle intensification [22]. Air temperatures have increased, on average, by $1{ }^{\circ} \mathrm{C}$, or $0.09^{\circ} \mathrm{C} /$ decade [23]. Precipitation has increased, on average, by $\sim 10 \mathrm{~mm} /$ decade [24], as have heavy downpours (events that are exceeded $1 \%$ of the time in any given year) which have increased by $71 \%$ in the Northeast and 37\% in the Midwest over the last three to five decades [25]. In West Virginia, a small state that is geographically central to the region and representative of the topographical, ecological, and climatological gradients of the area [26], minimum and maximum air temperatures have increased by $0.15{ }^{\circ} \mathrm{C}$ and $0.03^{\circ} \mathrm{C} /$ decade, respectively, while $\mathrm{P}$ has increased by $25 \mathrm{~mm} /$ decade since 1959 [26]. During the last half of the 20th century, mean annual $Q$, low flow, and base flow have all increased throughout the larger mid-Atlantic region [27-29]. Since 1951, the monthly $Q$ throughout the region has increased by 1 to $2 \mathrm{~mm} /$ year, with the largest increases during the fall and winter seasons due to increases in precipitation [29]. Coincidentally, the forest growing season length throughout the region has increased on average by 22 days since 1983 [30] as has $\mathrm{E}$, which has increased between 0.4 to $4 \mathrm{~mm} /$ year [30-32].

Fernandez and Zegre [16] quantified future changes in P and energy balance components for 420 counties and 13 states that comprise the Appalachian region, USA. The study found that both PET and $\mathrm{P}$ are projected to increase through the 21st century. $\mathrm{P}$ has been projected to become more variable through time; under Relative Concentration Pathways (RCP) 4.5 [33], where global atmospheric $\mathrm{CO}_{2}$ emissions are stabilized by mid-century, $\mathrm{P}$ is projected to increase during the first quarter of the 21st century (2006-2025), progressively decrease through mid-21st century (2026-2075), and then increase again late in the century (2076-2099). Under RCP8.5, where global atmospheric $\mathrm{CO}_{2}$ continues to increase unabated, $\mathrm{P}$ is projected to decrease early in the century, progressively increase through the 
mid-century, and continue to increase in the northern extent and decrease in the southern extent of the Appalachians. PET, on the other hand, is projected to progressively increase throughout the 21st century by $5 \%-20 \%$ (RCP4.5) and $20 \%-35 \%$ (RCP 8.5$)$ - a rate greater than P [16]. AI is projected to increase at higher elevations, shrinking the areas of headwaters [16] that have historically been characterized as energy limited (i.e., P exceeds PET) $[34,35]$ and are critical for maintaining downstream water availability $[2,36]$. Furthermore, $\mathrm{P}$ and PET are projected to become seasonally desynchronized, with $\mathrm{P}$ increasing during the dormant season and PET increasing during the growing season. Collectively, these changes have the potential to increase the occurrences of floods and droughts throughout the region [37-40], increasing the challenges of managing water resources under greater uncertainty and risk [36].

Despite the importance of this region as a freshwater source to local and downstream ecosystems and economies $[10,39,41]$, the sensitivity of forested catchments to climate change, and the implications for long-term water balance partitioning, are largely unknown. Previous studies have focused on single catchments, mixed-use catchments, or larger regional scales (e.g., mid-Atlantic, mid-western, northeastern US; Chesapeake Bay) [37-39,42,43] but the uniqueness of place and variations in topography, geography, land use, and landcover limit inference for catchment-scale decision making.

In this study, we quantified water balance sensitivity to changes in future climate using a simple Budyko-based energy model [14] to provide insight into how fresh water provisioning from forested catchments throughout the region might change due to anthropogenic climate change. Specifically, we quantified streamflow changes at the catchment scale and summarized them across basins and the region to provide watershed and natural resource managers and decision makers with information about climate change at scales relevant to decision making.

The objectives of this study are therefore to (1) quantify streamflow sensitivity to historical changes in climate in minimally impacted catchments; (2) quantify future climate change at the catchment-scale throughout the region; (3) model future $Q$ under two Relative Concentration Pathways to understand how future climate change might impact water resources availability throughout the region; and (4) evaluate spatial patterns of future streamflow sensitivity to climate.

\section{Materials and Methods}

\subsection{Data}

Mean daily streamflow were extracted for 29 catchments located across five dominant river basins across the region (Figure 1): the Monongahela, Upper Ohio, Kanawha, and Tennessee Rivers, which drain west to the Mississippi River and Gulf of Mexico, and the Potomac River, which drains east to Washington D.C. and the Chesapeake Bay. The 29 catchments represent $39 \%$ of the total area of the five river basins, with five catchments in the Monongahela, two in the Upper Ohio, six catchments in the Kanawha, three in the Tennessee, and 13 in the Potomac Basin (Figure 1). This largely forested region covers approximately $125,000 \mathrm{~km}^{2}$ and spans across eight states: West Virginia (WV), eastern Ohio $(\mathrm{OH})$, southwestern Pennsylvania (PA), eastern Kentucky (KY), western Virginia (VA), western North Carolina (NC), Maryland (MD), and western Tennessee (TN). Criteria for selecting the catchments were based on (1) inclusion in the U.S. Geological Survey Hydro-Climatic Data Network (HCDN) [44,45] and (2) a representative range of catchment areas (34-8101 km²) (Table 1). The HCDN consists of streamflow gaging station data for minimally impacted catchments $(<10 \%$ human influence, e.g., reservoirs, diversion, land use change, or severe ground-water pumping) identified as a subset of the national-scale USGS gauging stations and developed specifically for the purpose of studying the variation in surface-water conditions throughout the United States [45]. The HCDN data set has been used in many hydro climatic studies [28,46-51]. We extracted Q data from the national USGS Water Data dataset (https://waterdata.usgs.gov/nwis) from 1965-2004. While the World Meteorological Organization (WMO) recommends 30 years of continuous data to calculate "climate normals" [52], 
recent Budyko-based studies have used shorter time periods (e.g., 5-27 years) [51,53], based on the requirement of steady-state water balance conditions. [51].

A regional land cover analysis using the 2011 National Land Cover Database (NLCD) [54] was used to assess whether catchments still met the definition of being "minimally impacted" in the extended analysis period beyond the original NLCD. $Q$ data were normalized by area $\left(\mathrm{km}^{2}\right)$, converted to millimeters per year, and averaged to annual values using the USGS water-year (1 October-30 September).

Historic and future air temperature and $\mathrm{P}$ were extracted from the Multivariate Adaptive Constructed Analogs version 2 (MACAv2-METDATA) dataset [55]. MACA data are downscaled and bias corrected from Global Climate Models (GCMs) to a spatial resolution of gridded $4 \mathrm{~km}$ using non-parametric-quantile mapping and a constructed Analogs method [16,56]. The gridded climate values were averaged within the watershed boundaries. MACA only developed RCPs for 4.5 and 8.5, excluding 2.6 and $6.0[3,57]$. RCP4.5 represents a scenario in which greenhouse gas emissions are stabilized by the mid-21st century [57]. In RCP8.5, greenhouse gas emissions continue to rise with business as usual throughout the 21st century. In this study, 17 GCM models included in MACA were used to create ensemble climate data for the historic (1965-2004) period and for four approximate quarter-century periods of the 21st century: quarter 1, 2006-2025; quarter 2, 2026-2050; quarter 3, 2051-2075; and quarter 4, 2076-2099. Historical and future potential evapotranspiration (PET) were calculated for the region based on the Penman-Montieth method combined with the regional MACA dataset [16]. E was estimated using the annual water balance, $E=P-Q+\Delta S$, based on the USGS water year, where $P$ is the long-term average annual precipitation, $Q$ is the long-term average streamflow, and $\Delta S$ is watershed storage, which is assumed to approach zero over a long time period.

GCMs have known uncertainties and statistical biases that limit their direct use for hydrological assessments especially at short time scales, such as daily to weekly [58-60]. To tackle the issue of statistical biases, several correction techniques have been developed to adjust modelled variables to observations [61]. The MACA dataset has been developed using the data from CMIP 5 models and using a comprehensive six step downscaling and bias correcting approach and has been validated against observations [56]. The information from GCMs can also be informative if applied for long-term assessments [62]. Since our sensitivity analysis based on the Budyko model is a long-term water balance analysis, we considered the MACA dataset a viable tool to analyze possible change scenarios for the study catchments.

\subsection{Quantifying Historical Streamflow Sensitivity to Climate}

Streamflow sensitivity [35] is an elasticity-based method [63] based on the formulation of the Budyko equation [14] by Choudhury [64]. It includes the adjustable parameter, $n$, which accounts for non-climatic factors that influence E, such as slope, vegetation, geology, and soils using catchment-specific E variability [65]. The $\mathrm{n}$ value is calculated from the intersection of the $\mathrm{AI}(\mathrm{PET} / \mathrm{P})$ and evaporative index (ET/P) and plotted in the Budyko space based on the specific catchment parameters. The Budyko analysis incorporates intrinsic limitations due to the simplistic design structure and few required datasets. However, the approach is useful because it uses available data, and the macro-climatological processes within the Budyko analysis has been shown to meet the requirements for the long-term water balance and climatologic processes [66,67].

$$
\mathrm{E}=\frac{\mathrm{E} \times \mathrm{PET}}{\left(\mathrm{P}^{\mathrm{n}}+\mathrm{PET}^{\mathrm{n}}\right)^{1 / \mathrm{n}}}
$$

where $\mathrm{E}$ is long-term evapotranspiration, $\mathrm{PET}$ is long-term potential evapotranspiration, $\mathrm{P}$ is long-term precipitation, and $\mathrm{n}$ is a dimensionless parameter describing catchment properties that modify the partitioning of $\mathrm{P}$ into $\mathrm{E}$ and $\mathrm{Q}$. 
Table 1. Historical (1950-2004) water balance, Budyko, and streamflow sensitivity coefficients for selected USGS gaging stations and HCDN catchments in the central Appalachian Mountains region, US. P: precipitation; Q: streamflow; E: evapotranspiration; PET: potential evapotranspiration.

\begin{tabular}{|c|c|c|c|c|c|c|c|c|c|c|c|c|c|}
\hline \multirow{2}{*}{ Basin/Station Name } & \multirow[b]{2}{*}{ ID } & \multirow[b]{2}{*}{ Station Number } & \multirow[b]{2}{*}{ Area } & \multirow[b]{2}{*}{$\mathbf{P}$} & \multirow[b]{2}{*}{$\mathbf{Q}$} & \multirow[b]{2}{*}{$\mathbf{E}$} & \multirow[b]{2}{*}{ PET } & \multirow[b]{2}{*}{$\mathrm{PET} / \mathrm{P}$} & \multirow[b]{2}{*}{$\mathbf{E} / \mathbf{P}$} & \multirow[b]{2}{*}{$\mathbf{n}$} & \multicolumn{3}{|c|}{ Sensitivity Coefficeints } \\
\hline & & & & & & & & & & & $\Delta \mathbf{P} / \mathbf{P}$ & $\triangle \mathrm{PET} / \mathrm{PET}$ & $\Delta \mathrm{n} / \mathrm{n}$ \\
\hline & \multicolumn{13}{|c|}{ Monongahela } \\
\hline Casselman River at Grantsville, MD & $1 \mathrm{M}$ & 3078000 & 163 & 1172 & 678 & 494 & 1228 & 1.05 & 0.42 & 0.78 & 1.36 & -0.36 & 0.65 \\
\hline West Fork River at Enterprise, WV & $2 \mathrm{M}$ & 3061000 & 1965 & 1170 & 529 & 641 & 1310 & 1.12 & 0.55 & 1.06 & 1.57 & -0.57 & 0.79 \\
\hline Youghiogheny River near Oakland, MD & $3 \mathrm{M}$ & 3075500 & 347 & 1275 & 824 & 451 & 1203 & 0.94 & 0.35 & 0.69 & 1.28 & -0.28 & 0.55 \\
\hline Laurel Hill Creek at Ursina, PA & $4 \mathrm{M}$ & 3080000 & 313 & 1275 & 778 & 497 & 1203 & 0.94 & 0.39 & 0.76 & 1.33 & -0.33 & 0.58 \\
\hline Cheat River near Parsons, WV & $5 \mathrm{M}$ & 3069500 & 1869 & 1329 & 870 & 459 & 1215 & 0.91 & 0.35 & 0.68 & 1.27 & -0.27 & 0.54 \\
\hline Basin average & & & 932 & 1244 & 736 & 508 & 1232 & 0.99 & 0.41 & 0.79 & 1.36 & -0.36 & 0.62 \\
\hline \multicolumn{14}{|l|}{ Ohio } \\
\hline Little Shenango River at Greenville, PA & 10 & 3102500 & 269 & 1012 & 490 & 522 & 1253 & 1.24 & 0.52 & 0.91 & 1.48 & -0.48 & 0.81 \\
\hline Little Beaver Creek near East Liverpool, OH & $2 \mathrm{O}$ & 3109500 & 1284 & 1047 & 376 & 671 & 1316 & 1.26 & 0.64 & 1.26 & 1.76 & -0.76 & 0.97 \\
\hline Basin average & & & 777 & 1029 & 433 & 596 & 1285 & 1.25 & 0.58 & 1.08 & 1.62 & -0.62 & 0.89 \\
\hline \multicolumn{14}{|l|}{ Kanawha } \\
\hline Wolf Creek near Narrows, VA & $1 \mathrm{~K}$ & 3175500 & 577 & 1002 & 481 & 520 & 1414 & 1.41 & 0.52 & 0.85 & 1.46 & -0.46 & 0.87 \\
\hline Greenbrier River at Durbin, WV & $2 \mathrm{~K}$ & 3180500 & 344 & 1246 & 719 & 527 & 1187 & 0.95 & 0.42 & 0.83 & 1.37 & -0.37 & 0.61 \\
\hline Williams River at Dyer, WV & $3 \mathrm{~K}$ & 3186500 & 331 & 1479 & 949 & 530 & 1224 & 0.83 & 0.36 & 0.75 & 1.30 & -0.30 & 0.52 \\
\hline Big Coal River at Ashford, WV & $4 \mathrm{~K}$ & 3198500 & 1012 & 1196 & 490 & 706 & 1376 & 1.15 & 0.59 & 1.17 & 1.66 & -0.66 & 0.85 \\
\hline Bluestone River at Pipestem, WV & $5 \mathrm{~K}$ & 3179000 & 1020 & 1018 & 423 & 595 & 1381 & 1.36 & 0.58 & 1.02 & 1.59 & -0.59 & 0.94 \\
\hline Greenbrier River at Alderson, WV & $6 \mathrm{~K}$ & 3183500 & 3531 & 1080 & 520 & 560 & 1304 & 1.21 & 0.52 & 0.93 & 1.49 & -0.49 & 0.80 \\
\hline Basin average & & & 1136 & 1170 & 597 & 573 & 1314 & 1.15 & 0.50 & 0.92 & 1.48 & -0.48 & 0.76 \\
\hline \multicolumn{14}{|l|}{ Tennessee } \\
\hline North Fork Holston River near Saltsville, VA & $1 \mathrm{~T}$ & 3488000 & 572 & 1155 & 481 & 674 & 1435 & 1.24 & 0.58 & 1.08 & 1.62 & -0.62 & 0.89 \\
\hline Clinch River above Tazewell, TN & $2 \mathrm{~T}$ & 3528000 & 3816 & 1275 & 485 & 791 & 1433 & 1.12 & 0.62 & 1.30 & 1.75 & -0.75 & 0.87 \\
\hline Little Tennessee River near Prentiss, NC & $3 \mathrm{~T}$ & 3500000 & 362 & 1695 & 960 & 735 & 1443 & 0.85 & 0.43 & 0.92 & 1.41 & -0.41 & 0.57 \\
\hline Basin average & & & 1584 & 1375 & 642 & 733 & 1437 & 1.07 & 0.55 & 1.10 & 1.59 & -0.59 & 0.78 \\
\hline
\end{tabular}


Table 1. Cont

\begin{tabular}{|c|c|c|c|c|c|c|c|c|c|c|c|c|c|}
\hline \multirow{2}{*}{ Basin/Station Name } & \multirow[b]{2}{*}{ ID } & \multirow[b]{2}{*}{ Station Number } & \multirow[b]{2}{*}{ Area } & \multirow[b]{2}{*}{$\mathbf{P}$} & \multirow[b]{2}{*}{$\mathbf{Q}$} & \multirow[b]{2}{*}{ E } & \multirow[b]{2}{*}{ PET } & \multirow[b]{2}{*}{ PET/P } & \multirow[b]{2}{*}{$\mathbf{E} / \mathbf{P}$} & \multirow[b]{2}{*}{$\mathbf{n}$} & \multicolumn{3}{|c|}{ Sensitivity Coefficeints } \\
\hline & & & & & & & & & & & $\Delta \mathbf{P} / \mathbf{P}$ & $\triangle \mathrm{PET} / \mathrm{PET}$ & $\Delta \mathrm{n} / \mathrm{n}$ \\
\hline Potomac & & & & & & & & & & & & & \\
\hline Wills Creek near Cumberland, MD & $1 \mathrm{P}$ & 1601500 & 639 & 988 & 494 & 494 & 1352 & 1.37 & 0.50 & 0.82 & 1.44 & -0.44 & 0.83 \\
\hline Pototmac River near at Paw Paw, WV & $2 \mathrm{P}$ & 1610000 & 8101 & 988 & 398 & 591 & 1352 & 1.37 & 0.60 & 1.05 & 1.62 & -0.62 & 0.96 \\
\hline Cacapon River near Great Cacapon, WV & $3 \mathrm{P}$ & 1611500 & 1748 & 998 & 321 & 677 & 1387 & 1.39 & 0.68 & 1.29 & 1.84 & -0.83 & 1.09 \\
\hline Patterson Creek near Headsville, WV & $4 \mathrm{P}$ & 1604500 & 572 & 1071 & 283 & 788 & 1303 & 1.22 & 0.74 & 1.75 & 2.16 & -1.16 & 1.08 \\
\hline Bennett Creek at Park Mills, MD & $5 \mathrm{P}$ & 1634500 & 163 & 1040 & 399 & 641 & 1413 & 1.36 & 0.62 & 1.11 & 1.67 & -0.67 & 0.98 \\
\hline South Branch Potoamc River near Springfield, WV & $6 \mathrm{P}$ & 1608500 & 3783 & 973 & 347 & 626 & 1364 & 1.40 & 0.64 & 1.17 & 1.73 & -0.73 & 1.04 \\
\hline Conococheague Creek and Fairview, MD & $7 \mathrm{P}$ & 1614500 & 1279 & 1004 & 452 & 552 & 1404 & 1.40 & 0.55 & 0.92 & 1.52 & -0.52 & 0.90 \\
\hline Marsh Run at Grimes, MD & $8 \mathrm{P}$ & 1617800 & 49 & 1014 & 223 & 791 & 1427 & 1.41 & 0.78 & 1.76 & 2.26 & -1.26 & 1.31 \\
\hline North Branch Potomac River at Steyer, MD & $9 \mathrm{P}$ & 1595000 & 189 & 941 & 322 & 619 & 1342 & 1.43 & 0.66 & 1.20 & 1.76 & -0.76 & 1.08 \\
\hline Catoctin Creek near Middletown, MD & $10 \mathrm{P}$ & 1637500 & 173 & 1063 & 419 & 644 & 1424 & 1.34 & 0.61 & 1.09 & 1.65 & -0.65 & 0.96 \\
\hline Goose Creek near Leesburg, VA & $11 \mathrm{P}$ & 1644000 & 860 & 1081 & 366 & 715 & 1441 & 1.33 & 0.66 & 1.27 & 1.80 & -0.80 & 1.04 \\
\hline North Fork Shenandoah River at Cootes Store, VA & $12 \mathrm{P}$ & 1632000 & 544 & 995 & 348 & 647 & 1382 & 1.39 & 0.65 & 1.20 & 1.75 & -0.75 & 1.05 \\
\hline Cedar Creek near Winchester, VA & $13 \mathrm{P}$ & 1643500 & 264 & 1040 & 366 & 674 & 1413 & 1.36 & 0.65 & 1.22 & 1.76 & -0.76 & 1.03 \\
\hline Basin average & & & 1413 & 1015 & 364 & 651 & 1385 & 1.37 & 0.64 & 1.22 & 1.76 & -0.76 & 1.03 \\
\hline Regional average & & & 1246 & 1125 & 510 & 615 & 1342 & 1.22 & 0.56 & 1.06 & 1.61 & -0.61 & 0.87 \\
\hline \pm std. dev. & & & 1671 & 167 & 198 & 98 & 82 & 0.19 & 0.11 & 0.26 & 0.23 & 0.23 & 0.20 \\
\hline
\end{tabular}


Equation (1) can be used to quantify the change in E due to changes in climate (P, PET) and $n$ [35]:

$$
\Delta \mathrm{E}=\frac{\partial \mathrm{E}}{\partial \mathrm{P}} \Delta \mathrm{P}+\frac{\partial \mathrm{E}}{\partial \mathrm{PET}} \Delta \mathrm{PET}+\frac{\partial \mathrm{E}}{\partial \mathrm{n}} \Delta \mathrm{n}
$$

The respective partial differentials are given by Equations (3a)-(3c), which provide insight into how changes in climate (P, PET) and land cover (n) affect E.

$$
\begin{gathered}
\frac{\partial \mathrm{E}}{\partial \mathrm{P}}=\frac{\mathrm{E}}{\mathrm{P}}\left(\frac{\mathrm{PET}^{\mathrm{n}}}{\mathrm{P}^{\mathrm{n}}+\mathrm{PET}^{\mathrm{n}}}\right) \\
\frac{\partial \mathrm{E}}{\partial \mathrm{PET}}=\frac{\mathrm{E}}{\mathrm{PET}}\left(\frac{\mathrm{P}^{\mathrm{n}}}{\mathrm{P}^{\mathrm{n}}+\mathrm{PET}^{\mathrm{n}}}\right) \\
\frac{\partial \mathrm{E}}{\partial \mathrm{n}}=\frac{\mathrm{E}}{\mathrm{n}}\left(\frac{\ln \left(\mathrm{P}^{\mathrm{n}}+\mathrm{PET}^{\mathrm{n}}\right)}{\mathrm{n}}\right)-\frac{\left(\mathrm{P}^{\mathrm{n}} \ln \mathrm{P}+\mathrm{PET}^{\mathrm{n}} \ln \mathrm{PET}\right)}{\mathrm{P}^{\mathrm{n}}+\mathrm{PET}^{\mathrm{n}}}
\end{gathered}
$$

It is assumed that the water balance changes over time are from one steady state to another steady state [35]; i.e., that transient changes in storage can be ignored [67]. Based on this assumption, $Q$ was calculated by

$$
\Delta \mathrm{Q}=\Delta \mathrm{P}-\Delta \mathrm{E}
$$

By combining Equations (2) and (4), $\Delta \mathrm{Q}$ is given by

$$
\Delta \mathrm{Q}=\left(1-\frac{\partial \mathrm{E}}{\partial \mathrm{P}}\right) \Delta \mathrm{P}-\frac{\partial \mathrm{E}}{\partial \mathrm{PET}} \Delta \mathrm{PET}-\frac{\partial \mathrm{E}}{\partial \mathrm{n}} \Delta \mathrm{n}
$$

Relative $\Delta \mathrm{Q}$ is then solved by

$$
\frac{\Delta \mathrm{Q}}{\mathrm{Q}}=\left[\frac{\mathrm{P}}{\mathrm{Q}}\left(1-\frac{\partial \mathrm{E}}{\partial \mathrm{P}}\right)\right] \frac{\Delta \mathrm{P}}{\mathrm{P}}-\left[\frac{\mathrm{PET}}{\mathrm{Q}} \frac{\partial \mathrm{E}}{\partial \mathrm{PET}}\right] \frac{\Delta \mathrm{PET}}{\mathrm{PET}}-\left[\frac{\mathrm{n}}{\mathrm{Q}} \frac{\partial \mathrm{E}}{\partial \mathrm{n}}\right] \frac{\Delta \mathrm{n}}{\mathrm{n}}
$$

The terms in square brackets are the sensitivity coefficients expressing the effect of changing $P$ and PET on relative $\Delta \mathrm{Q}$ (Table 1 ), where $\Delta \mathrm{P} / \mathrm{P}$ represents the theoretical sensitivity of streamflow to changes in precipitation, $\triangle \mathrm{PET} / \mathrm{PET}$ represents the sensitivity of streamflow to changes in energy (PET), and $\Delta \mathrm{n} / \mathrm{n}$ represents the change in $\mathrm{Q}$ following a change in watershed characteristics. An increase in $\Delta \mathrm{P} / \mathrm{P}$ will increase $\mathrm{Q}$, while an increase in $\Delta \mathrm{PET} / \mathrm{PET}$ and $\Delta \mathrm{n} / \mathrm{n}$ will decrease $\mathrm{Q}$.

\subsection{Modeling Future Streamflow}

The sensitivity of future $Q$ to future changes in $P$ and PET was modeled using historical sensitivity coefficients and future climates based on ensemble RCP4.5 and RCP8.5 data. Future changes in P and PET were calculated relative to the historical period $(\mathrm{H})$ :

$$
\begin{gathered}
\frac{\Delta \mathrm{P}}{\mathrm{P}} \mathrm{RCP}, \mathrm{x}=\frac{\mathrm{P}_{\mathrm{RCP}, \mathrm{x}}-\mathrm{P}_{\mathrm{H}}}{\mathrm{P}_{\mathrm{H}}} \\
\frac{\Delta \mathrm{PET}}{\mathrm{PET}} \mathrm{RCP}, \mathrm{x}=\frac{\mathrm{PET}_{\mathrm{RCP}, \mathrm{x}}-\mathrm{PET}_{\mathrm{H}}}{\mathrm{PET}_{\mathrm{H}}}
\end{gathered}
$$

Substituting future values of $\mathrm{P}$ and PET into Equation (5) with the historical sensitivity coefficients for $\mathrm{P}$ and PET (Equations (3a)-(3c)), future $\Delta \mathrm{Q}$ was quantified by

$$
\Delta \mathrm{Q}=\left(1-\frac{\Delta \mathrm{P}}{\mathrm{P}}\right) \Delta \mathrm{P}_{\mathrm{RCP}, \mathrm{x}}-\frac{\Delta \mathrm{PET}}{\mathrm{PET}} \Delta \mathrm{PET}_{\mathrm{RCP}, \mathrm{x}}-\frac{\Delta \mathrm{n}}{\mathrm{n}} \Delta \mathrm{n}
$$

Because our analysis focused on HCDN catchments, we assumed that catchment properties (parameter $\mathrm{n}$ ) do not change in the future, thereby setting the $\mathrm{n}$ sensitivity coefficient and $\mathrm{dn}$ to 
0 . We recognize that this assumption is likely an oversimplification of future landscape conditions, particularly in light of changes in forest structure, age, productivity, and growing season length $[32,68,69]$ in relatively undisturbed catchments throughout the region. Future analysis should consider dn to more thoroughly account for ecosystem changes important to the partition of $\mathrm{P}$ into $\mathrm{E}$ and $\mathrm{Q}$.

\section{Results}

\subsection{Historic Climate, Water Balance Components, and Streamflow Sensitivity throughout the Central Appalachian Mountains Region}

Long-term average annual climate, water balance, and Budyko components over the historical period (1965-2004) are summarized in Table 1. Annual precipitation averaged $1125 \pm 167 \mathrm{~mm}$ across the region. $\mathrm{P}$ was greatest in the Tennessee basin $(\overline{\mathrm{x}}=1375 \mathrm{~mm})$, followed by the Monongahela $(\overline{\mathrm{x}}=1244 \mathrm{~mm})$, Kanawha $(\overline{\mathrm{x}}=1170 \mathrm{~mm})$, Ohio $(\overline{\mathrm{x}}=1029 \mathrm{~mm})$, and the Potomac $(\overline{\mathrm{x}}=1015 \mathrm{~mm})$. Annual $Q$ averaged $510 \pm 198 \mathrm{~mm}$ across the region and was greatest in the Monongahela basin $(\bar{x}=736 \mathrm{~mm})$, followed by the Tennessee $(\bar{x}=642 \mathrm{~mm})$, Kanawha $(\bar{x}=597 \mathrm{~mm})$, Ohio $(\bar{x}=433 \mathrm{~mm})$ and the Potomac $(\bar{x}=364 \mathrm{~mm})$. Annual E and PET averaged $615 \pm 98 \mathrm{~mm}$ and $1342 \pm 83 \mathrm{~mm}$, respectively, generally following a south-to-north gradient. E was greatest in the Tennessee basin $(\bar{x}=733 \mathrm{~mm})$, followed by the Potomac $(\bar{x}=651 \mathrm{~mm})$, Ohio $(\bar{x}=596 \mathrm{~mm})$, Kanawha $(\bar{x}=573 \mathrm{~mm})$, and Monongahela $(\bar{x}=508 \mathrm{~mm})$. PET averaged $1437 \mathrm{~mm}$ in the Tennessee, $1385 \mathrm{~mm}$ in the Potomac, $1314 \mathrm{~mm}$ in the Kanawha, $1285 \mathrm{~mm}$ in the Ohio, and $1232 \mathrm{~mm}$ in the Monongahela.

The aridity index, AI, averaged $1.22 \pm 0.19$ across the region, and was greatest in the Potomac $(\bar{x}=1.37)$ and smallest in the Monongahela basin $(\bar{x}=0.99)$ (Table 1). The evaporation ratio, E/P, which represents the proportion of $\mathrm{P}$ returned to the atmosphere through actual $\mathrm{E}$, averaged $0.56 \pm 0.11$ across the region. Similar to AI, E/P was greatest in the Potomac $(\bar{x}=0.64)$ and smallest in the Monongahela basin $(\bar{x}=0.41)$ (Figure 2). The catchment-specific landscape parameter, $n$, averaged $1.61 \pm 0.23$ across the region, and was greatest in the Potomac $(\bar{x}=1.76)$ and smallest in the Monongahela basin $(\bar{x}=0.79)$ (Figure 3).

Streamflow sensitivity coefficients, which quantify the historical sensitivity of $Q$ to changes in climate and catchment properties, averaged $1.61 \pm 0.23(\Delta \mathrm{P} / \mathrm{P}), 0.61 \pm 0.23(\triangle \mathrm{PET} / \mathrm{PET})$, and $0.87 \pm$ $0.20 \Delta \mathrm{n} / \mathrm{n}$ ) across the region (Table 1). These imply that $\mathrm{Q}$ is more sensitive to $\Delta \mathrm{P}$ than $\Delta \mathrm{PET}$ and $\Delta \mathrm{n}$. Based on this, the theoretical results from Equation (6) predict that, for example, a 10\% increase in $P$ would increase $Q$ by $16 \%$, while a $10 \%$ increase in PET would decrease $Q$ by $6 \%$, and a $10 \%$ increase in landcover change would decrease $Q$ by $8.7 \%$ [35] (Figure 4).
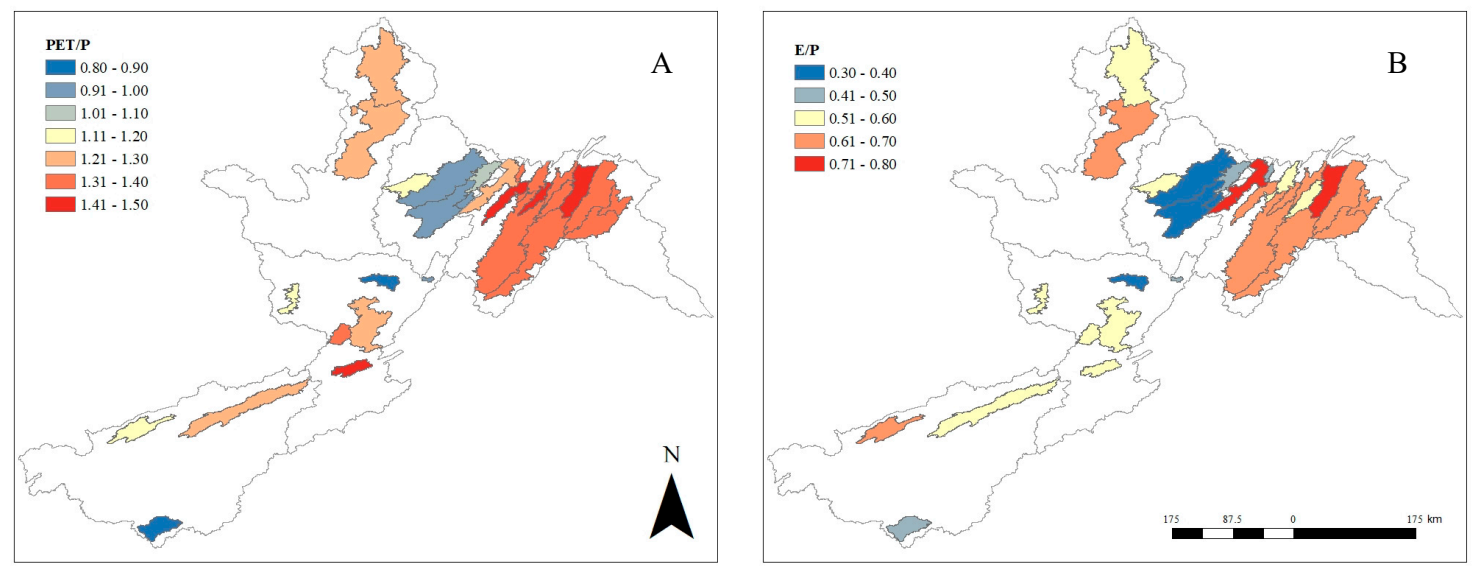

Figure 2. Historical (2965-2005) (A) aridity index (PET/P) and (B) evaporative index (E/P). 

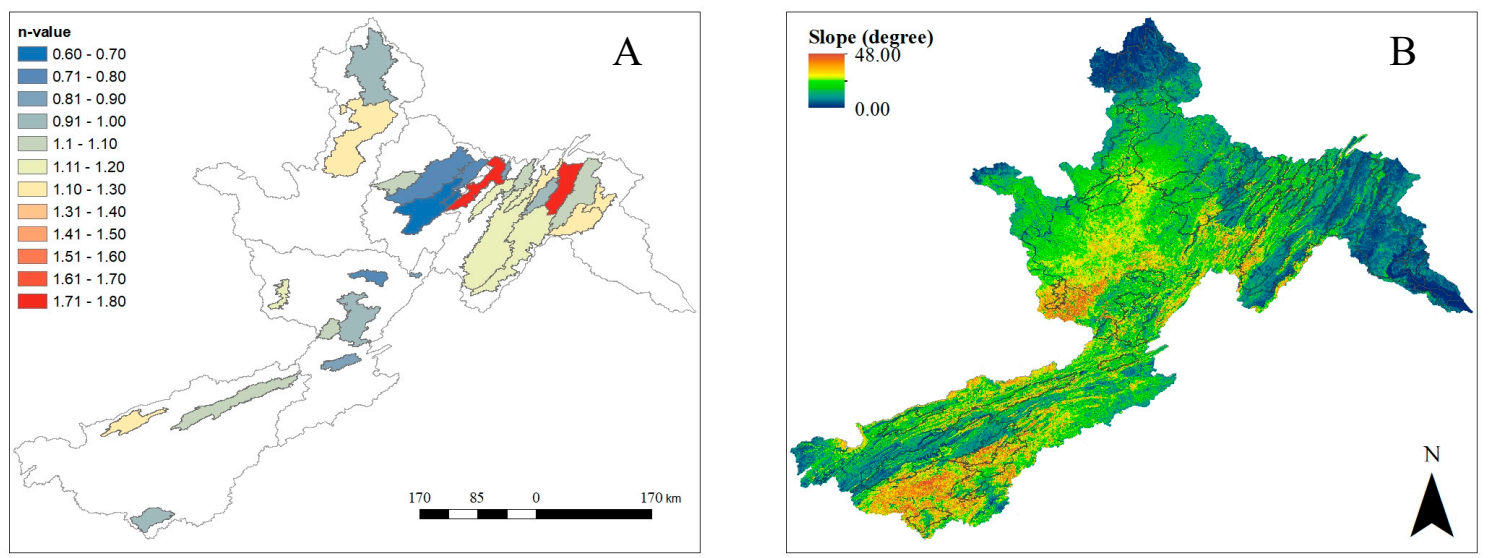

Figure 3. Landcover characteristics displayed as (A) the $n$ value and (B) slope in degrees.
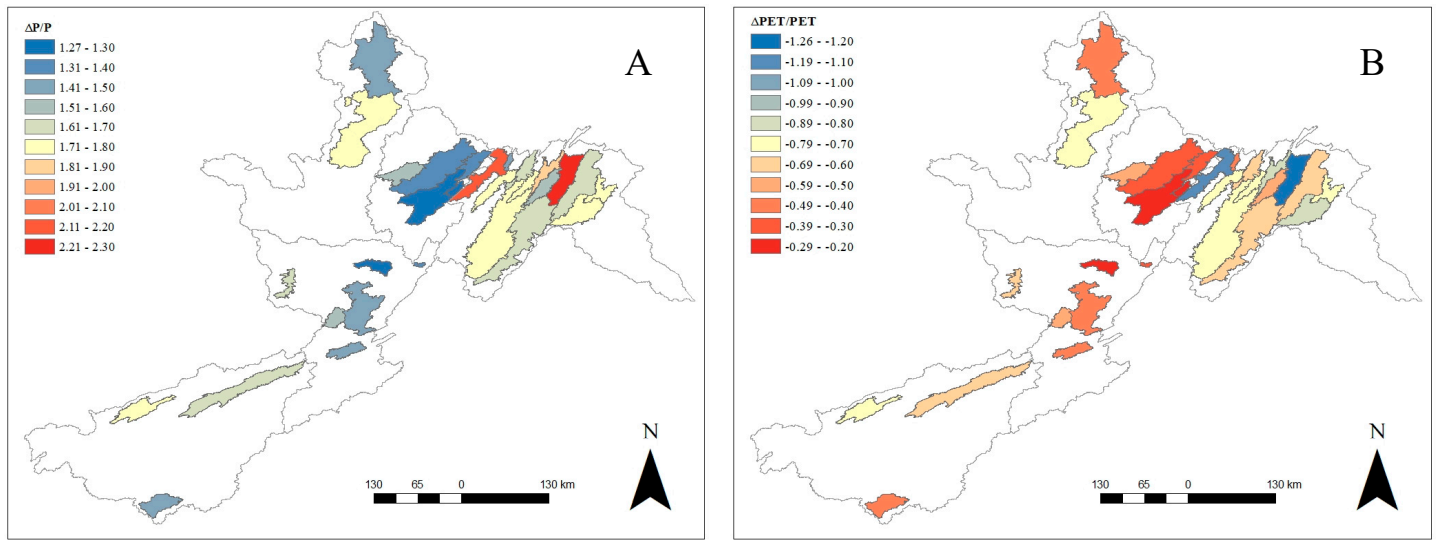

Figure 4. Sensitivity of streamflow to changes in (A) precipitation and (B) PET using data from 1965-2004.

\subsection{Twenty-First Century Climate and Streamflow}

Future climates (P, PET, AI) are summarized by RCP in Tables 2 and 3. For each pathway, P, PET, and $\mathrm{AI}$ at the catchment scale were projected to increase over the 21st century, albeit at different rates. Relative to the historic period, $\mathrm{P}$ was projected to increase in all catchments on average by $4 \%$ and $8 \%$ over the century for RCP4.5 and RCP8.5, respectively. Changes were greatest during the last quarter (2075-2099) of the 21st century, with P increasing between 1\%-14\% for RCP4.5 and 5\%-15\% for RCP8.5. PET is projected to progressively increase throughout the 21 st century by $10 \%$ and $15 \%$, on average, for RCP4.5 and RCP8.5, respectively.

Similar to $P$, the greatest changes in PET were in Quarter 4, increasing between $11 \%-17 \%$ for RCP4.5 and 5\%-15\% for RCP8.5. Changes in AI largely follow patterns in P and PET, increasing on average by $4 \%$ for RCP4.5 and $9 \%$ for RCP8.5 throughout the region. By the end of the century, AI was projected to be greatest over the study period, with changes ranging between $0.2 \%-11 \%$ (RCP4.5) and $8 \%-22 \%$ (RCP8.5).

Future $\mathrm{Q}$ are summarized in Table 4 and Figures 5 and 6. $\mathrm{Q}$ is projected to increase across catchments, basins, and the region under RCP4.5, with $93 \%-100 \%$ of catchments experiencing positive changes over the century. Changes across catchments were generally similar in magnitude when averaged across basins and ranged between $9 \%$ to $13 \%$ and. Under RCP8.5, Q was projected to be more variable in the future, decreasing by as much as $9 \%$ and increasing by as much as $9 \%$ (Table 4 ). $Q$ increased early (2005-2025) in the century, with 28/29 catchments experiencing greater $Q$ relative to the historic period. $Q$ progressively decreased throughout the century, with nearly half of the catchments experiencing decreases in Q by mid- and late-century periods. 
Table 2. Future (2005-2099) long-term annual precipitation (P), potential evapotranspiration (PET), and aridity index (AI) and changes by quarter for RCP4.5 for selected HCDN catchments.

\begin{tabular}{|c|c|c|c|c|c|c|c|c|c|c|c|c|c|c|c|c|c|c|c|c|c|c|c|c|}
\hline \multirow{2}{*}{$\begin{array}{c}\text { RCP4.5 } \\
\text { Basin/Station Name }\end{array}$} & \multicolumn{6}{|c|}{ Q1 (2005-2025) } & \multicolumn{6}{|c|}{ Q2 (2026-2050) } & \multicolumn{6}{|c|}{ Q3 (2051-2075) } & \multicolumn{6}{|c|}{ Q4 (2076-2099) } \\
\hline & $\mathbf{P}$ & DP & PET & DPET & AI & DAI & $\mathbf{P}$ & DP & PET & DPET & AI & DAI & $\mathbf{P}$ & DP & PET & DPET & AI & DAI & $\mathbf{P}$ & DP & PET & DPET & AI & DAI \\
\hline Monongahela & $\mathrm{mm}$ & $\%$ & $\mathrm{~mm}$ & $\%$ & - & $\%$ & $\mathrm{~mm}$ & $\%$ & $\mathrm{~mm}$ & $\%$ & - & $\%$ & $\mathrm{~mm}$ & $\%$ & $\mathrm{~mm}$ & $\%$ & - & $\%$ & $\mathrm{~mm}$ & $\%$ & $\mathrm{~mm}$ & $\%$ & - & $\%$ \\
\hline $\begin{array}{c}\text { Casselman River at } \\
\text { Grantsville, MD }\end{array}$ & 1217 & 4 & 1302 & 6 & 1.07 & 2 & 1230 & 5 & 1349 & 10 & 1.10 & 5 & 1245 & 6 & 1389 & 13 & 1.12 & 7 & 1266 & 8 & 1396 & 14 & 1.10 & 5 \\
\hline $\begin{array}{l}\text { West Fork River at } \\
\text { Enterprise, WV }\end{array}$ & 1212 & 4 & 1385 & 6 & 1.14 & 2 & 1228 & 5 & 1430 & 9 & 1.16 & 4 & 1247 & 7 & 1467 & 12 & 1.18 & 5 & 1260 & 8 & 1475 & 13 & 1.17 & 5 \\
\hline $\begin{array}{c}\text { Youghiogheny River } \\
\text { near Oakland, MD }\end{array}$ & 1324 & 4 & 1275 & 6 & 0.96 & 2 & 1340 & 5 & 1321 & 10 & 0.99 & 5 & 1359 & 7 & 1359 & 13 & 1.00 & 6 & 1374 & 8 & 1367 & 14 & 0.99 & 5 \\
\hline $\begin{array}{l}\text { Laurel Hill Creek } \\
\text { at Ursina, PA }\end{array}$ & 1298 & 2 & 1318 & 10 & 1.02 & 8 & 1313 & 3 & 1364 & 13 & 1.04 & 10 & 1331 & 4 & 1402 & 17 & 1.05 & 12 & 1347 & 6 & 1410 & 17 & 1.05 & 11 \\
\hline $\begin{array}{l}\text { Cheat River near } \\
\text { Parsons, WV }\end{array}$ & 1379 & 4 & 1288 & 6 & 0.93 & 2 & 1394 & 5 & 1336 & 10 & 0.96 & 5 & 1418 & 7 & 1372 & 13 & 0.97 & 6 & 1430 & 8 & 1381 & 14 & 0.97 & 6 \\
\hline Basin average & 1286 & 3 & 1314 & 7 & 1.03 & 3 & 1301 & 5 & 1360 & 10 & 1.05 & 6 & 1320 & 6 & 1398 & 14 & 1.06 & 7 & 1335 & 7 & 1406 & 14 & 1.06 & 6 \\
\hline Ohio & & & & & & & & & & & & & & & & & & & & & & & & \\
\hline $\begin{array}{l}\text { Little Shenango River } \\
\text { at Greenville, PA }\end{array}$ & 1058 & 4 & 1328 & 6 & 1.26 & 1 & 1066 & 5 & 1372 & 10 & 1.29 & 4 & 1084 & 7 & 1412 & 13 & 1.30 & 5 & 1090 & 8 & 1421 & 13 & 1.30 & 5 \\
\hline $\begin{array}{c}\text { Little Beaver Creek } \\
\text { near East Liverpool, OH }\end{array}$ & 1084 & 4 & 1394 & 6 & 1.29 & 2 & 1099 & 5 & 1438 & 9 & 1.31 & 4 & 1116 & 7 & 1476 & 12 & 1.32 & 5 & 1123 & 7 & 1485 & 13 & 1.32 & 5 \\
\hline Basin average & 1071 & 4 & 1361 & 6 & 1.27 & 2 & 1083 & 5 & 1405 & 9 & 1.30 & 4 & 1100 & 7 & 1444 & 12 & 1.31 & 5 & 1106 & 7 & 1453 & 13 & 1.31 & 5 \\
\hline Kanawha & & & & & & & & & & & & & & & & & & & & & & & & \\
\hline $\begin{array}{l}\text { Wolf Creek near } \\
\text { Narrows, VA }\end{array}$ & 1040 & 4 & 1486 & 5 & 1.43 & 1 & 1047 & 4 & 1537 & 9 & 1.47 & 4 & 1063 & 6 & 1570 & 11 & 1.48 & 5 & 1076 & 7 & 1579 & 12 & 1.47 & 4 \\
\hline $\begin{array}{l}\text { Greenbrier River } \\
\text { at Durbin, WV }\end{array}$ & 1298 & 4 & 1259 & 6 & 0.97 & 2 & 1316 & 6 & 1309 & 10 & 0.99 & 4 & 1331 & 7 & 1345 & 13 & 1.01 & 6 & 1349 & 8 & 1354 & 14 & 1.00 & 5 \\
\hline $\begin{array}{l}\text { Williams River } \\
\text { at Dyer, WV }\end{array}$ & 1533 & 4 & 1293 & 6 & 0.84 & 2 & 1548 & 5 & 1341 & 10 & 0.87 & 5 & 1569 & 6 & 1376 & 12 & 0.88 & 6 & 1586 & 7 & 1385 & 13 & 0.87 & 6 \\
\hline $\begin{array}{l}\text { Big Coal River } \\
\text { at Ashford, WV }\end{array}$ & 1235 & 3 & 1451 & 5 & 1.18 & 2 & 1242 & 4 & 1500 & 9 & 1.21 & 5 & 1261 & 5 & 1531 & 11 & 1.21 & 6 & 1274 & 7 & 1543 & 12 & 1.21 & 5 \\
\hline $\begin{array}{l}\text { Bluestone River } \\
\text { at Pipestem, WV }\end{array}$ & 1058 & 4 & 1453 & 5 & 1.37 & 1 & 1062 & 4 & 1504 & 9 & 1.42 & 4 & 1079 & 6 & 1537 & 11 & 1.42 & 5 & 1090 & 7 & 1547 & 12 & 1.42 & 5 \\
\hline $\begin{array}{l}\text { Greenbrier River } \\
\text { at Alderson, WV }\end{array}$ & 1123 & 4 & 1373 & 5 & 1.22 & 1 & 1127 & 4 & 1422 & 9 & 1.26 & 5 & 1143 & 6 & 1455 & 12 & 1.27 & 6 & 1157 & 7 & 1465 & 12 & 1.27 & 5 \\
\hline Basin average & 1214 & 4 & 1386 & 5 & 1.17 & 2 & 1223 & 5 & 1436 & 9 & 1.20 & 5 & 1241 & 6 & 1469 & 12 & 1.21 & 5 & 1255 & 7 & 1479 & 13 & 1.21 & 5 \\
\hline
\end{tabular}


Table 2. Cont

\begin{tabular}{|c|c|c|c|c|c|c|c|c|c|c|c|c|c|c|c|c|c|c|c|c|c|c|c|c|}
\hline \multirow{2}{*}{$\begin{array}{c}\text { RCP4.5 } \\
\text { Basin/Station Name }\end{array}$} & \multicolumn{6}{|c|}{ Q1 (2005-2025) } & \multicolumn{6}{|c|}{ Q2 (2026-2050) } & \multicolumn{6}{|c|}{ Q3 (2051-2075) } & \multicolumn{6}{|c|}{ Q4 (2076-2099) } \\
\hline & $\mathbf{P}$ & DP & PET & DPET & AI & DAI & $\mathbf{P}$ & DP & PET & DPET & [ AI & DAI & $\mathbf{P}$ & DP & PET & DPET & I AI & DAI & $\mathbf{P}$ & DP & PET & DPET & AI & DAI \\
\hline \multicolumn{25}{|l|}{ Tennessee } \\
\hline $\begin{array}{l}\text { North Fork Holston } \\
\text { River near Saltsville, VA }\end{array}$ & 1195 & 3 & 1516 & 6 & 1.27 & 2 & 1196 & 4 & 1569 & 9 & 1.31 & 6 & 1222 & 6 & 1597 & 11 & 1.31 & 5 & 1236 & 7 & 1608 & 12 & 1.30 & 5 \\
\hline $\begin{array}{l}\text { Clinch River above } \\
\text { Tazewell, TN }\end{array}$ & 1319 & 3 & 1503 & 5 & 1.14 & 1 & 1309 & 3 & 1556 & 9 & 1.19 & 6 & 1342 & 5 & 1582 & 10 & 1.18 & 5 & 1354 & 6 & 1595 & 11 & 1.18 & 5 \\
\hline $\begin{array}{l}\text { Little Tennessee River } \\
\text { near Prentiss, NC }\end{array}$ & 1753 & 3 & 1512 & 5 & 0.86 & 1 & 1745 & 3 & 1567 & 9 & 0.90 & 6 & 1793 & 6 & 1599 & 11 & 0.89 & 5 & 1819 & 7 & 1612 & 12 & 0.89 & 4 \\
\hline Basin average & 1422 & 3 & 1510 & 5 & 1.09 & 2 & 1417 & 3 & 1564 & 9 & 1.13 & 6 & 1452 & 6 & 1593 & 11 & 1.13 & 5 & 1469 & 7 & 1605 & 12 & 1.12 & 5 \\
\hline \multicolumn{25}{|l|}{ Potomac } \\
\hline $\begin{array}{l}\text { Wills Creek near } \\
\text { Cumberland, MD }\end{array}$ & 1025 & 4 & 1429 & 6 & 1.39 & 2 & 1038 & 5 & 1475 & 9 & 1.42 & 4 & 1048 & 6 & 1515 & 12 & 1.44 & 6 & 1070 & 8 & 1522 & 13 & 1.42 & 4 \\
\hline $\begin{array}{l}\text { Pototmac River near at } \\
\text { Paw Paw, WV }\end{array}$ & 994 & 1 & 1436 & 6 & 1.44 & 6 & 1005 & 2 & 1482 & 10 & 1.47 & 8 & 1017 & 3 & 1522 & 13 & 1.50 & 9 & 1037 & 5 & 1529 & 13 & 1.47 & 8 \\
\hline $\begin{array}{l}\text { Cacapon River near } \\
\text { Great Cacapon, WV }\end{array}$ & 1040 & 4 & 1465 & 6 & 1.41 & 1 & 1049 & 5 & 1510 & 9 & 1.44 & 4 & 1062 & 6 & 1550 & 12 & 1.46 & 5 & 1084 & 9 & 1558 & 12 & 1.44 & 3 \\
\hline $\begin{array}{l}\text { Patterson Creek near } \\
\text { Headsville, WV }\end{array}$ & 1112 & 4 & 1379 & 6 & 1.24 & 2 & 1126 & 5 & 1426 & 9 & 1.27 & 4 & 1139 & 6 & 1466 & 12 & 1.29 & 6 & 1156 & 8 & 1473 & 13 & 1.27 & 5 \\
\hline $\begin{array}{l}\text { Bennett Creek at } \\
\text { Park Mills, MD }\end{array}$ & 1084 & 4 & 1489 & 5 & 1.37 & 1 & 1098 & 6 & 1538 & 9 & 1.40 & 3 & 1110 & 7 & 1576 & 12 & 1.42 & 5 & 1135 & 9 & 1584 & 12 & 1.40 & 3 \\
\hline $\begin{array}{c}\text { South Branch Potoamc } \\
\text { River near Springfield, WV }\end{array}$ & 1013 & 4 & 1441 & 6 & 1.42 & 2 & 1025 & 5 & 1488 & 9 & 1.45 & 4 & 1036 & 7 & 1529 & 12 & 1.47 & 5 & 1057 & 9 & 1536 & 13 & 1.45 & 4 \\
\hline $\begin{array}{l}\text { Conococheague Creek } \\
\text { and Fairview, MD }\end{array}$ & 1046 & 4 & 1481 & 5 & 1.42 & 1 & 1057 & 5 & 1527 & 9 & 1.45 & 3 & 1070 & 7 & 1567 & 12 & 1.46 & 5 & 1092 & 9 & 1575 & 12 & 1.44 & 3 \\
\hline $\begin{array}{l}\text { Marsh Run at } \\
\text { Grimes, MD }\end{array}$ & 1059 & 4 & 1505 & 5 & 1.42 & 1 & 1066 & 5 & 1551 & 9 & 1.46 & 4 & 1080 & 6 & 1592 & 12 & 1.47 & 5 & 1104 & 9 & 1599 & 12 & 1.45 & 3 \\
\hline $\begin{array}{l}\text { North Branch Potomac } \\
\text { River at Steyer, MD }\end{array}$ & 980 & 4 & 1419 & 6 & 1.45 & 2 & 992 & 5 & 1466 & 9 & 1.48 & 4 & 1003 & 7 & 1505 & 12 & 1.50 & 5 & 1019 & 8 & 1513 & 13 & 1.48 & 4 \\
\hline $\begin{array}{l}\text { Catoctin Creek near } \\
\text { Middletown, MD }\end{array}$ & 1109 & 4 & 1501 & 5 & 1.35 & 1 & 1115 & 5 & 1548 & 9 & 1.39 & 4 & 1130 & 6 & 1589 & 12 & 1.41 & 5 & 1158 & 9 & 1597 & 12 & 1.38 & 3 \\
\hline $\begin{array}{c}\text { Goose Creek near } \\
\text { Leesburg, VA }\end{array}$ & 1129 & 4 & 1518 & 5 & 1.34 & 1 & 1136 & 5 & 1566 & 9 & 1.38 & 3 & 1153 & 7 & 1606 & 11 & 1.39 & 5 & 1179 & 9 & 1614 & 12 & 1.37 & 3 \\
\hline $\begin{array}{l}\text { North Fork Shenandoah } \\
\text { River at Cootes Store, VS }\end{array}$ & 1037 & 4 & 1458 & 6 & 1.41 & 1 & 1052 & 6 & 1509 & 9 & 1.43 & 3 & 1064 & 7 & 1548 & 12 & 1.45 & 5 & 1085 & 9 & 1556 & 13 & 1.44 & 3 \\
\hline $\begin{array}{l}\text { Cedar Creek near } \\
\text { Winchester, VA }\end{array}$ & 1136 & 9 & 1513 & 7 & 1.33 & -2 & 1137 & 9 & 1560 & 10 & 1.37 & 1 & 1155 & 11 & 1600 & 13 & 1.39 & 2 & 1181 & 14 & 1609 & 14 & 1.36 & 0.2 \\
\hline Basin average & 1059 & 4 & 1464 & 6 & 1.38 & 1.40 & 1069 & 5 & 1511 & 9 & 1.42 & 4 & 1082 & 7 & 1551 & 12 & 1.44 & 5 & 1104 & 9 & 1559 & 13 & 1.41 & 4 \\
\hline Regional average & 1169 & 4 & 1420 & 6 & 1 & 2 & 1178 & 5 & 1468 & 9 & 1 & 4 & 1196 & 6 & 1505 & 12 & 1 & 6 & 1213 & 8 & 1513 & 13 & 1 & 5 \\
\hline \pm std. dev & 171 & 1.3 & 82 & 0.8 & 0.2 & 1.5 & 169 & 1.3 & 83 & 0.9 & 0.2 & 1.6 & 175 & 1.2 & 82 & 1.1 & 0.2 & 1.6 & 175 & 1.5 & 83 & 1.1 & 0.2 & 1.8 \\
\hline
\end{tabular}


Table 3. Future (2005-2099) long-term annual precipitation (P), potential evapotranspiration (PET), and aridity index (AI) and changes by quarter for RCP8.5 for selected HCDN catchments.

\begin{tabular}{|c|c|c|c|c|c|c|c|c|c|c|c|c|c|c|c|c|c|c|c|c|c|c|c|c|}
\hline \multirow{2}{*}{$\begin{array}{c}\text { RCP8.5 } \\
\text { Basin/Station Name }\end{array}$} & \multicolumn{6}{|c|}{ Q1 (2005-2025) } & \multicolumn{6}{|c|}{ Q2 (2026-2050) } & \multicolumn{6}{|c|}{ Q3 (2051-2075) } & \multicolumn{6}{|c|}{ Q4 (2076-2099) } \\
\hline & $\mathbf{P}$ & DP & PET & DPET & AI & DAI & $\mathbf{P}$ & DP & PET & DPET & AI & DAI & $\mathbf{P}$ & DP & PET & DPET & AI & DAI & $\mathbf{P}$ & DP & PET & DPET & AI & DAI \\
\hline & $\mathrm{mm}$ & $\%$ & $\mathrm{~mm}$ & $\%$ & - & $\%$ & $\mathrm{~mm}$ & $\%$ & $\mathrm{~mm}$ & $\%$ & - & $\%$ & $\mathrm{~mm}$ & $\%$ & $\mathrm{~mm}$ & $\%$ & - & $\%$ & $\mathrm{~mm}$ & $\%$ & $\mathrm{~mm}$ & $\%$ & - & $\%$ \\
\hline \multicolumn{25}{|l|}{ Monongahela } \\
\hline $\begin{array}{l}\text { Casselman River at Grantsville, MD } \\
\text { West Fork River at Enternrise WV }\end{array}$ & 1223 & 4 & $\begin{array}{l}1322 \\
1406\end{array}$ & $\begin{array}{l}8 \\
7\end{array}$ & 1.08 & 3 & 1227 & 5 & 1375 & 12 & 1.12 & 7 & 1248 & 6 & 1471 & 20 & 1.18 & 12 & 1276 & 9 & 1547 & & 1.21 & 15 \\
\hline West Fork River at Enterprise, WV & 1223 & 5 & 1406 & 7 & 1.15 & 4 & 1223 & 5 & 1456 & 11 & 1.19 & 7 & 1241 & 6 & 1549 & 18 & 1.25 & 12 & 1272 & 9 & 1621 & 24 & 1.27 & 15 \\
\hline Youghiogheny River near Oakland, MD & 1328 & 4 & 1295 & 8 & 0.97 & 4 & 1334 & 5 & 1345 & 12 & 1.01 & 7 & 1355 & 6 & 1437 & 20 & 1.06 & 13 & 1385 & 9 & 1510 & 26 & 1.09 & 16 \\
\hline Laurel Hill Creek at Ursina, PA & 1308 & 3 & 1339 & 11 & 1.02 & 9 & 1309 & 3 & 1390 & 16 & 1.06 & 13 & 1327 & 4 & 1484 & 23 & 1.12 & 19 & 1358 & 7 & 1558 & 30 & 1.15 & 22 \\
\hline Cheat River near Parsons, WV & 1386 & 4 & 1310 & 8 & 0.95 & 4 & 1390 & 5 & 1361 & 12 & 0.98 & 8 & 1409 & 6 & 1455 & 20 & 1.03 & 13 & 1438 & 8 & 1529 & 26 & 1.06 & 17 \\
\hline Basin average & 1294 & 4 & 1334 & 8 & 1.03 & 5 & 1297 & 4 & 1385 & 13 & 1.07 & 8 & 1316 & 6 & 1479 & 20 & 1.13 & 14 & 1346 & 8 & 1553 & 26 & 1.16 & 17 \\
\hline \multicolumn{25}{|l|}{ Ohio } \\
\hline Little Shenango River at & 1069 & 6 & 1346 & 7 & 1.26 & 2 & 1066 & 5 & 1399 & 12 & 1.31 & 6 & 1074 & 6 & 1495 & 19 & 1.39 & 13 & 1115 & 10 & 1571 & 25 & 1.41 & 14 \\
\hline Little Beaver Creek near East Liverpool, $\mathrm{OH}$ & 1096 & 5 & 1413 & 7 & 1.29 & 2 & 1097 & 5 & 1465 & 11 & 1.34 & 6 & 1106 & 6 & 1561 & 19 & 1.41 & 12 & 1141 & 9 & 1635 & 24 & 1.43 & 14 \\
\hline Basin average & 1083 & 5 & 1379 & 7 & 1.27 & 2 & 1082 & 5 & 1432 & 11 & 1.32 & 6 & 1090 & 6 & 1528 & 19 & 1.40 & 12 & 1128 & 10 & 1603 & 25 & 1.42 & 14 \\
\hline \multicolumn{25}{|l|}{ Kanawha } \\
\hline Wolf Creek near Narrows, VA & 1034 & 3 & 1507 & 7 & 1.46 & 3 & 1049 & 5 & 1558 & 10 & 1.49 & 5 & 1066 & 6 & 1646 & 16 & 1.54 & 9 & 1080 & 8 & 1725 & 22 & 1.60 & 13 \\
\hline Greenbrier River at Durbin, WV & 1294 & 4 & 1280 & 8 & 0.99 & 4 & 1308 & 5 & 1332 & 12 & 1.02 & 7 & 1334 & 7 & 1424 & 20 & 1.07 & 12 & 1353 & 9 & 1500 & 26 & 1.11 & 16 \\
\hline Williams River at Dyer, WV & 1536 & 4 & 1314 & 7 & 0.86 & 3 & 1541 & 4 & 1364 & 11 & 0.89 & 7 & 1561 & 6 & 1454 & 19 & 0.93 & 13 & 1586 & 7 & 1527 & 25 & 0.96 & 16 \\
\hline Big Coal River at Ashford, WV & 1232 & 3 & 1477 & 7 & 1.20 & 4 & 1235 & 3 & 1525 & 11 & 1.23 & 7 & 1249 & 4 & 1616 & 17 & 1.29 & 13 & 1272 & 6 & 1690 & 23 & 1.33 & 16 \\
\hline Bluestone River at Pipestem, WV & 1053 & 3 & 1476 & 7 & 1.40 & 3 & 1067 & 5 & 1526 & 11 & 1.43 & 6 & 1076 & 6 & 1619 & 17 & 1.50 & 11 & 1092 & 7 & 1699 & 23 & 1.56 & 15 \\
\hline Greenbrier River at Alderson, WV & 1117 & 3 & 1395 & 7 & 1.25 & 4 & 1130 & 5 & 1444 & 11 & 1.28 & 6 & 1144 & 6 & 1531 & 17 & 1.34 & 11 & 1160 & 7 & 1605 & 23 & 1.38 & 15 \\
\hline Basin average & 1211 & 3 & 1408 & 7 & 1.19 & 4 & 1222 & 4 & 1458 & 11 & 1.22 & 6 & 1238 & 6 & 1548 & 18 & 1.28 & 11 & 1257 & 7 & 1624 & 24 & 1.32 & 15 \\
\hline \multicolumn{25}{|l|}{ Tennessee } \\
\hline North Fork Holston River near Saltsville, VA & 1194 & 3 & 1539 & 7 & 1.29 & 4 & 1202 & 4 & 1588 & 11 & 1.32 & 6 & 1211 & 5 & 1676 & 17 & 1.38 & 11 & 1226 & 6 & 1753 & 22 & 1.43 & 15 \\
\hline Clinch River above Tazewell, TN & 1318 & 3 & 1528 & 7 & 1.16 & 3 & 1316 & 3 & 1576 & 10 & 1.20 & 6 & 1322 & 4 & 1659 & 16 & 1.26 & 12 & 1343 & 5 & 1726 & 20 & 1.29 & 14 \\
\hline Little Tennessee River near Prentiss, NC & 1766 & 4 & 1533 & 6 & 0.87 & 2 & 1765 & 4 & 1586 & 10 & 0.90 & 6 & 1780 & 5 & 1675 & 16 & 0.94 & 11 & 1780 & 5 & 1753 & 22 & 0.98 & 16 \\
\hline Basin average & 1426 & 4 & 1533 & 7 & 1.11 & 3 & 1428 & 4 & 1583 & 10 & 1.14 & 6 & 1437 & 5 & 1670 & 16 & 1.19 & 11 & 1449 & 5 & 1744 & 21 & 1.23 & 15 \\
\hline \multicolumn{25}{|l|}{ Potomac } \\
\hline Wills Creek near Cumberland, MD & 1032 & 4 & 1449 & 7 & 1.40 & 3 & 1037 & 5 & 1501 & 11 & 1.45 & 6 & 1056 & 7 & 1595 & 18 & 1.51 & 10 & 1080 & 9 & 1669 & 23 & 1.55 & 13 \\
\hline Pototmac River near Great Cacapon, WV & 999 & 1 & 1455 & 8 & 1.46 & 6 & 1005 & 2 & 1508 & 12 & 1.50 & 10 & 1023 & 4 & 1601 & 18 & 1.56 & 14 & 1046 & 6 & 1675 & 24 & 1.60 & 17 \\
\hline Cacapon River near Great Cacapon, WV & 1044 & 5 & 1483 & 7 & 1.42 & 2 & 1050 & 5 & 1537 & 11 & 1.46 & 5 & 1069 & 7 & 1629 & 17 & 1.52 & 10 & 1096 & 10 & 1703 & 23 & 1.55 & 12 \\
\hline Patterson Creek near Headsville, WV & 1116 & 4 & 1399 & 7 & 1.25 & 3 & 1122 & 5 & 1452 & 11 & 1.29 & 6 & 1143 & 7 & 1547 & 19 & 1.35 & 11 & 1168 & 9 & 1621 & 24 & 1.39 & 14 \\
\hline Bennett Creek at Park Mills, MD & 1078 & 4 & 1509 & 7 & 1.40 & 3 & 1095 & 5 & 1564 & 11 & 1.43 & 5 & 1123 & 8 & 1656 & 17 & 1.47 & 9 & 1143 & 10 & 1733 & 23 & 1.52 & 12 \\
\hline South Branch Potoamc River near Springfield, WV & 1017 & 4 & 1460 & 7 & 1.44 & 2 & 1024 & 5 & 1515 & 11 & 1.48 & 6 & 1043 & 7 & 1609 & 18 & 1.54 & 10 & 1066 & 10 & 1685 & 24 & 1.58 & 13 \\
\hline Conococheague Creek and Fairview, MD & 1049 & 4 & 1500 & 7 & 1.43 & 2 & 1058 & 5 & 1554 & 11 & 1.47 & 5 & 1078 & 7 & 1647 & 17 & 1.53 & 9 & 1105 & 10 & 1722 & 23 & 1.56 & 12 \\
\hline Marsh Run at Grimes, MD & 1061 & 5 & 1524 & 7 & 1.44 & 2 & 1068 & 5 & 1579 & 11 & 1.48 & 5 & 1088 & 7 & 1673 & 17 & 1.54 & 9 & 1119 & 10 & 1748 & 22 & 1.56 & 11 \\
\hline North Branch Potomac River at Steyer, MD & 981 & 4 & 1439 & 7 & 1.47 & 3 & 989 & 5 & 1492 & 11 & 1.51 & 6 & 1009 & 7 & 1586 & 18 & 1.57 & 10 & 1030 & 9 & 1661 & 24 & 1.61 & 13 \\
\hline Catoctin Creek near Middletown, MD & 1109 & 4 & 1521 & 7 & 1.37 & 2 & 1119 & 5 & 1577 & 11 & 1.41 & 5 & 1140 & 7 & 1669 & 17 & 1.46 & 9 & 1172 & 10 & 1745 & 23 & 1.49 & 11 \\
\hline Goose Creek near Leesburg, VA & 1126 & 4 & 1538 & 7 & 1.37 & 2 & 1138 & 5 & 1594 & 11 & 1.40 & 5 & 1164 & 8 & 1686 & 17 & 1.45 & 9 & 1191 & 10 & 1763 & 22 & 1.48 & 11 \\
\hline North Fork Shenandoah River at Cootes Store, VS & 1032 & 4 & 1480 & 7 & 1.43 & 3 & 1048 & 5 & 1536 & 11 & 1.47 & 6 & 1074 & 8 & 1631 & 18 & 1.52 & 9 & 1093 & 10 & 1710 & 24 & 1.56 & 13 \\
\hline Cedar Creek near Winchester, VA & 1131 & 9 & 1532 & 8 & 1.35 & 0 & 1141 & 10 & 1589 & 12 & 1.39 & 2 & 1163 & 12 & 1680 & 19 & 1.44 & 6 & 1198 & 15 & 1755 & 24 & 1.46 & 8 \\
\hline Basin average & 1060 & 4 & 1484 & 7 & 1.40 & 3 & 1069 & 5 & 1538 & 11 & 1.44 & 6 & 1090 & 7 & 1632 & 18 & 1.50 & 10 & 1116 & 10 & 1707 & 23 & 1.53 & 12 \\
\hline Regional average & 1174 & 4 & 1441 & 7 & 1.25 & 3.2 & 1180 & 5 & 1493 & 11 & 1.29 & 6 & 1198 & 6 & 1585 & 18 & 1.35 & 11 & 1222 & 8 & 1659 & 24 & 1.38 & 14 \\
\hline std. dev & 167 & 1 & 83 & 1 & 0.18 & 1.5 & 165 & 1 & 84 & 1 & 0.19 & 2 & 165 & 2 & 83 & 2 & 0.19 & 2 & 162 & 2 & 83 & 2 & 0.19 & 3 \\
\hline
\end{tabular}


Table 4. Future (2005-2099) changes in long-term annual streamflow $(\Delta \mathrm{Q})$ due to changes in precipitation $\left(\Delta \mathrm{Q}_{\mathrm{P}}\right)$ and potential evapotranspiration $\left(\Delta \mathrm{Q}_{\mathrm{PET}}\right)$ relative to the historical period (1950-2004) based on RCP4.5 and RCP8.5.

\begin{tabular}{|c|c|c|c|c|c|c|c|c|c|c|c|c|c|c|c|c|c|c|c|c|c|c|c|c|}
\hline \multirow[b]{2}{*}{ Basin /Station Name } & \multicolumn{3}{|c|}{$\begin{array}{l}\mathrm{Q} 1 \\
(2005-2025)\end{array}$} & \multicolumn{3}{|c|}{$\begin{array}{l}\mathrm{Q} 2 \\
(2026-2050)\end{array}$} & \multicolumn{3}{|c|}{$\begin{array}{l}\mathrm{Q3} \\
(2051-2075)\end{array}$} & \multicolumn{3}{|c|}{$\begin{array}{l}\mathrm{Q} 4 \\
(2076-2099)\end{array}$} & \multicolumn{3}{|c|}{$\begin{array}{l}\mathrm{Q1} \\
\text { (2005-2025) }\end{array}$} & \multicolumn{3}{|c|}{$\begin{array}{l}\mathrm{Q} 2 \\
(2026-2050)\end{array}$} & \multicolumn{3}{|c|}{$\begin{array}{l}\mathrm{Q3} \\
(2051-2075)\end{array}$} & \multicolumn{3}{|c|}{$\begin{array}{l}\mathrm{Q} 4 \\
(2076-2099)\end{array}$} \\
\hline & $\begin{array}{c}\mathrm{DQ}_{\mathrm{P}} \\
\%\end{array}$ & $\underset{\substack{\mathrm{Q} \\
\mathrm{Q}}}{\mathrm{D}}$ & $\begin{array}{c}\mathrm{DQ} \\
\%\end{array}$ & $\begin{array}{c}\mathrm{DQP}_{\mathrm{P}} \\
\%\end{array}$ & $\underset{\substack{\mathrm{QPET} \\
\text { Q }}}{\mathrm{D}}$ & $\begin{array}{c}\mathrm{DQ} \\
\%\end{array}$ & $\begin{array}{c}\mathrm{DQP} \\
\%\end{array}$ & $\underset{\%}{\mathrm{D}}$ & $\begin{array}{c}\mathrm{DQ} \\
\%\end{array}$ & $\begin{array}{c}\mathrm{DQ}_{\mathrm{P}} \\
\%\end{array}$ & $\underset{\substack{\mathrm{QPET} \\
\mathrm{Q}}}{\mathrm{D}}$ & $\begin{array}{c}\mathrm{DQ} \\
\%\end{array}$ & $\begin{array}{c}\mathrm{DQ}_{\mathrm{P}} \\
\%\end{array}$ & $\underset{\%}{\mathbf{D P E T}}$ & $\begin{array}{c}\mathrm{DQ} \\
\%\end{array}$ & $\begin{array}{c}\mathrm{DQ}_{\mathrm{P}} \\
\%\end{array}$ & $\begin{array}{c}\mathrm{D} \\
\underset{\mathrm{Q}}{\mathrm{PET}} \\
\mathrm{\%}\end{array}$ & $\begin{array}{c}\mathrm{DQ} \\
\%\end{array}$ & $\begin{array}{c}\mathrm{DQ}_{\mathrm{P}} \\
\%\end{array}$ & $\begin{array}{c}\mathrm{D} \\
\underset{\mathrm{Q}}{\mathrm{OPT}}\end{array}$ & $\begin{array}{c}\mathrm{DQ} \\
\%\end{array}$ & $\begin{array}{l}\mathrm{DQ}_{\mathrm{P}} \\
\%\end{array}$ & $\underset{\substack{\mathrm{QPET} \\
\text { Q }}}{\mathrm{D}}$ & $\begin{array}{c}\mathrm{DQ} \\
\%\end{array}$ \\
\hline \multicolumn{25}{|l|}{ Monongahela } \\
\hline $\begin{array}{l}\text { Casselman River at } \\
\text { Grantsville, MD }\end{array}$ & 5 & -2 & 3 & 7 & -4 & 3 & 8 & -5 & 4 & 11 & -5 & 6 & 6 & -3 & 3 & 6 & -4 & 2 & 9 & -7 & 2 & 12 & -9 & 3 \\
\hline $\begin{array}{l}\text { West Fork River at } \\
\text { Enterprise, WV }\end{array}$ & 6 & -3 & 2 & 8 & -5 & 3 & 10 & -7 & 4 & 12 & -7 & 5 & 7 & -4 & 3 & 7 & -6 & 1 & 10 & -10 & -1 & 14 & -14 & 0 \\
\hline $\begin{array}{l}\text { Youghiogheny River near } \\
\text { Oakland, MD }\end{array}$ & 5 & -2 & 3 & 7 & -3 & 4 & 8 & -4 & 5 & 10 & -4 & 6 & 5 & -2 & 3 & 6 & -3 & 3 & 8 & -5 & 3 & 11 & -7 & 4 \\
\hline $\begin{array}{l}\text { Laurel Hill Creek at } \\
\text { Ursina, PA }\end{array}$ & 2 & -3 & -1 & 4 & -4 & 0 & 6 & -5 & 0 & 7 & -6 & 2 & 3 & -4 & 0 & 4 & -5 & -2 & 5 & -8 & -2 & 9 & -10 & -1 \\
\hline $\begin{array}{l}\text { Cheat River near Parsons, } \\
\text { WV }\end{array}$ & 5 & -2 & 3 & 6 & -3 & 4 & 9 & -4 & 5 & 10 & -4 & 6 & 5 & -2 & 3 & 6 & -3 & 3 & 8 & -5 & 2 & 10 & -7 & 3 \\
\hline Basin average & 5 & -2 & 2 & 6 & -4 & 3 & 8 & -5 & 3 & 10 & -5 & 5 & 5 & -3 & 2 & 6 & -5 & 1 & 8 & -7 & 1 & 11 & -9 & 2 \\
\hline \multicolumn{25}{|l|}{ Ohio } \\
\hline $\begin{array}{l}\text { Little Shenango River at } \\
\text { Greenville, PA }\end{array}$ & 7 & -3 & 4 & 8 & -5 & 3 & 11 & -6 & 4 & 11 & -6 & 5 & 8 & -4 & 5 & 8 & -6 & 2 & 9 & -9 & 0 & 15 & -12 & 3 \\
\hline $\begin{array}{l}\text { Little Beaver Creek near } \\
\text { East Liverpool, OH }\end{array}$ & 6 & -5 & 2 & 9 & -7 & 2 & 12 & -9 & 2 & 13 & -10 & 3 & 8 & -6 & 3 & 9 & -9 & 0 & 10 & -14 & -4 & 16 & -19 & -3 \\
\hline Basin average & 6 & -4 & 3 & 8 & -6 & 3 & 11 & -8 & 3 & 12 & -8 & 4 & 8 & -5 & 4 & 8 & -7 & 1 & 9 & -12 & -2 & 16 & -15 & 0 \\
\hline \multicolumn{25}{|l|}{ Kanawha } \\
\hline $\begin{array}{l}\text { Wolf Creek near Narrows, } \\
\text { VA }\end{array}$ & 6 & -2 & 3 & 7 & -4 & 3 & 9 & -5 & 4 & 11 & -5 & 5 & 5 & -3 & 2 & 7 & -5 & 2 & 9 & -8 & 2 & 11 & -10 & 1 \\
\hline $\begin{array}{l}\text { Greenbrier River at } \\
\text { Durbin, WV }\end{array}$ & 6 & -2 & 3 & 8 & -4 & 4 & 9 & -5 & 4 & 11 & -5 & 6 & 5 & -3 & 2 & 7 & -5 & 2 & 10 & -7 & 2 & 12 & -10 & 2 \\
\hline $\begin{array}{l}\text { Williams River at Dyer, } \\
\text { WV }\end{array}$ & 5 & -2 & 3 & 6 & -3 & 3 & 8 & -4 & 4 & 9 & -4 & 5 & 5 & -2 & 3 & 5 & -3 & 2 & 7 & -6 & 2 & 9 & -7 & 2 \\
\hline $\begin{array}{l}\text { Big Coal River at Ashford, } \\
\text { WV }\end{array}$ & 5 & -4 & 2 & 6 & -6 & 0 & 9 & -7 & 2 & 11 & -8 & 3 & 5 & -5 & 0 & 5 & -7 & -2 & 7 & -12 & -4 & 11 & -15 & -5 \\
\hline $\begin{array}{l}\text { Bluestone River at } \\
\text { Pipestem, WV }\end{array}$ & 6 & -3 & 3 & 7 & -5 & 2 & 9 & -7 & 3 & 11 & -7 & 4 & 5 & -4 & 1 & 8 & -6 & 1 & 9 & -10 & -1 & 12 & -14 & -2 \\
\hline $\begin{array}{l}\text { Greenbrier River at } \\
\text { Alderson, WV }\end{array}$ & 6 & -3 & 3 & 6 & -4 & 2 & 9 & -6 & 3 & 11 & -6 & 4 & 5 & -3 & 2 & 7 & -5 & 2 & 9 & -9 & 0 & 11 & -11 & 0 \\
\hline Basin average & 6 & -3 & 3 & 7 & -4 & 2 & 9 & -6 & 3 & 11 & -6 & 5 & 5 & -3 & 2 & 6 & -5 & 1 & 9 & -9 & 0 & 11 & -11 & 0 \\
\hline
\end{tabular}


Table 4. Cont.

\begin{tabular}{|c|c|c|c|c|c|c|c|c|c|c|c|c|c|c|c|c|c|c|c|c|c|c|c|c|}
\hline \multirow[b]{2}{*}{ Basin /Station Name } & \multicolumn{3}{|c|}{$\begin{array}{l}\text { Q1 } \\
\text { (2005-2025) }\end{array}$} & \multicolumn{3}{|c|}{$\begin{array}{l}\mathrm{Q} 2 \\
(2026-2050)\end{array}$} & \multicolumn{3}{|c|}{$\begin{array}{l}\text { Q3 } \\
\text { (2051-2075) }\end{array}$} & \multicolumn{3}{|c|}{$\begin{array}{l}\text { Q4 } \\
(2076-2099)\end{array}$} & \multicolumn{3}{|c|}{$\begin{array}{l}\text { Q1 } \\
(2005-2025)\end{array}$} & \multicolumn{3}{|c|}{$\begin{array}{l}\text { Q2 } \\
(2026-2050)\end{array}$} & \multicolumn{3}{|c|}{$\begin{array}{l}\text { Q3 } \\
(2051-2075)\end{array}$} & \multicolumn{3}{|c|}{$\begin{array}{l}\text { Q4 } \\
(2076-2099)\end{array}$} \\
\hline & $\begin{array}{c}\mathrm{DQ}_{\mathrm{P}} \\
\%\end{array}$ & $\begin{array}{c}\text { D } \\
\text { QPET } \\
\% \\
\end{array}$ & $\begin{array}{c}\mathrm{DQ} \\
\%\end{array}$ & $\begin{array}{c}\mathrm{DQ}_{\mathrm{P}} \\
\% \\
\end{array}$ & $\begin{array}{c}\text { D } \\
\text { QPET } \\
\%\end{array}$ & $\begin{array}{c}\mathrm{DQ} \\
\%\end{array}$ & $\begin{array}{c}\mathrm{DQ} \\
\%\end{array}$ & $\begin{array}{c}\text { D } \\
\text { QPET } \\
\%\end{array}$ & $\begin{array}{c}\mathrm{DQ} \\
\%\end{array}$ & $\begin{array}{c}\mathrm{DQ}_{\mathrm{P}} \\
\%\end{array}$ & $\begin{array}{c}\text { D } \\
\text { QPET } \\
\%\end{array}$ & $\begin{array}{c}\mathrm{DQ} \\
\%\end{array}$ & $\begin{array}{c}\mathrm{DQ}_{\mathrm{P}} \\
\%\end{array}$ & $\begin{array}{c}\text { D } \\
\text { QPET } \\
\%\end{array}$ & $\begin{array}{c}\mathrm{DQ} \\
\%\end{array}$ & $\begin{array}{c}\mathrm{DQ} \\
\%\end{array}$ & $\begin{array}{c}\mathrm{D} \\
\text { QPET } \\
\%\end{array}$ & $\begin{array}{c}\mathrm{DQ} \\
\%\end{array}$ & $\begin{array}{c}\mathrm{DQ}_{\mathrm{P}} \\
\%\end{array}$ & $\begin{array}{c}\text { D } \\
\text { QPET } \\
\%\end{array}$ & $\begin{array}{c}\mathrm{DQ} \\
\%\end{array}$ & $\begin{array}{c}\mathrm{DQ}_{\mathrm{P}} \\
\%\end{array}$ & $\begin{array}{c}\text { D } \\
\text { QPET } \\
\%\end{array}$ & $\begin{array}{c}\mathrm{DQ} \\
\%\end{array}$ \\
\hline \multicolumn{25}{|l|}{ Tennessee } \\
\hline $\begin{array}{l}\text { North Fork Holston River } \\
\text { near Saltsville, VA }\end{array}$ & 6 & -3 & 2 & 6 & -6 & 0 & 9 & -7 & 2 & 11 & -7 & 4 & 6 & -4 & 1 & 7 & -7 & 0 & 8 & -10 & -3 & 10 & -14 & -4 \\
\hline $\begin{array}{l}\text { Clinch River above } \\
\text { Tazewell, TN }\end{array}$ & 6 & -4 & 2 & 5 & -6 & -2 & 9 & -8 & 1 & 11 & -9 & 2 & 6 & -5 & 1 & 6 & -7 & -2 & 6 & -12 & -5 & 9 & -15 & -6 \\
\hline $\begin{array}{l}\text { Little Tennessee River } \\
\text { near Prentiss, NC }\end{array}$ & 5 & -2 & 3 & 4 & -4 & 1 & 8 & -4 & 4 & 10 & -5 & 5 & 6 & -3 & 3 & 6 & -4 & 2 & 7 & -7 & 0 & 7 & -9 & -2 \\
\hline Basin average & 6 & -3 & 2 & 5 & -5 & 0 & 9 & -6 & 2 & 11 & -7 & 4 & 6 & -4 & 2 & 6 & -6 & 0 & 7 & -10 & -2 & 9 & -13 & -4 \\
\hline \multicolumn{25}{|l|}{ Potomac } \\
\hline $\begin{array}{l}\text { Wills Creek near } \\
\text { Cumberland, MD }\end{array}$ & 5 & -2 & 3 & 7 & -4 & 3 & 9 & -5 & 3 & 12 & -5 & 6 & 6 & -3 & 3 & 7 & -5 & 2 & 10 & -8 & 2 & 13 & -10 & 3 \\
\hline $\begin{array}{l}\text { Pototmac River near at } \\
\text { Paw Paw, WV }\end{array}$ & 1 & -4 & -3 & 3 & -6 & -3 & 5 & -8 & -3 & 8 & -8 & 0 & 2 & -5 & -3 & 3 & -7 & -4 & 6 & -11 & -6 & 10 & -15 & -5 \\
\hline $\begin{array}{l}\text { Cacapon River near Great } \\
\text { Cacapon, WV }\end{array}$ & 8 & -5 & 3 & 9 & -7 & 2 & 12 & -10 & 2 & 16 & -10 & 6 & 9 & -6 & 3 & 10 & -9 & 1 & 13 & -15 & -1 & 18 & -19 & -1 \\
\hline $\begin{array}{l}\text { Patterson Creek near } \\
\text { Headsville, WV }\end{array}$ & 8 & -7 & 2 & 11 & -11 & 0 & 14 & -14 & -1 & 17 & -15 & 2 & 9 & -8 & 1 & 10 & -13 & -3 & 15 & -22 & -7 & 20 & -28 & -9 \\
\hline $\begin{array}{l}\text { Bennett Creek at Park } \\
\text { Mills, MD } \\
\text { South Branch Potoamc }\end{array}$ & 7 & -4 & 3 & 9 & -6 & 3 & 11 & -8 & 4 & 15 & -8 & 7 & 6 & -5 & 2 & 9 & -7 & 2 & 13 & -12 & 2 & 16 & -15 & 1 \\
\hline $\begin{array}{l}\text { River near Springfield, } \\
\text { WV }\end{array}$ & 7 & -4 & 3 & 9 & -7 & 3 & 11 & -9 & 3 & 15 & -9 & 6 & 8 & -5 & 3 & 9 & -8 & 1 & 12 & -13 & -1 & 17 & -17 & -1 \\
\hline $\begin{array}{l}\text { Conococheague Creek } \\
\text { and Fairview, MD }\end{array}$ & 6 & -3 & 3 & 8 & -5 & 3 & 10 & -6 & 4 & 13 & -6 & 7 & 7 & -4 & 3 & 8 & -6 & 2 & 11 & -9 & 2 & 15 & -12 & 3 \\
\hline $\begin{array}{l}\text { Marsh Run at Grimes, } \\
\text { MD }\end{array}$ & 10 & -7 & 3 & 11 & -11 & 0 & 15 & -15 & 0 & 20 & -15 & 5 & 10 & -9 & 2 & 12 & -13 & -1 & 16 & -22 & -5 & 23 & -28 & -5 \\
\hline $\begin{array}{l}\text { North Branch Potomac } \\
\text { River at Steyer, MD }\end{array}$ & 7 & -4 & 3 & 9 & -7 & 2 & 12 & -9 & 2 & 15 & -10 & 5 & 7 & -5 & 2 & 9 & -8 & 0 & 13 & -14 & -1 & 17 & -18 & -1 \\
\hline $\begin{array}{l}\text { Catoctin Creek near } \\
\text { Middletown, MD }\end{array}$ & 7 & -4 & 4 & 8 & -6 & 2 & 10 & -8 & 3 & 15 & -8 & 7 & 7 & -4 & 3 & 9 & -7 & 2 & 12 & -11 & 1 & 17 & -15 & 2 \\
\hline $\begin{array}{l}\text { Goose Creek near } \\
\text { Leesburg, VA }\end{array}$ & 8 & -4 & 4 & 9 & -7 & 2 & 12 & -9 & 3 & 16 & -10 & 7 & 8 & -5 & 2 & 9 & -9 & 1 & 14 & -14 & 0 & 18 & -18 & 0 \\
\hline $\begin{array}{l}\text { North Fork Shenandoah } \\
\text { River at Cootes Store, VS }\end{array}$ & 7 & -4 & 3 & 10 & -7 & 3 & 12 & -9 & 3 & 16 & -9 & 6 & 6 & -5 & 1 & 9 & -8 & 1 & 14 & -13 & 0 & 17 & -18 & -1 \\
\hline $\begin{array}{l}\text { Cedar Creek near } \\
\text { Winchester, VA }\end{array}$ & 16 & -5 & 11 & 16 & -8 & 9 & 19 & -10 & 9 & 24 & -11 & 13 & 15 & -6 & 9 & 17 & -9 & 8 & 21 & -14 & 6 & 27 & -18 & 8 \\
\hline Basin average & 8 & -4 & 3 & 9 & -7 & 2 & 12 & -9 & 2 & 15 & -10 & 6 & 8 & -5 & 2 & 9 & -8 & 1 & 13 & -14 & -1 & 17 & -18 & 0 \\
\hline Regional average & 6 & -3 & 3 & 8 & -6 & 2 & 10 & -7 & 3 & 13 & -8 & 5 & 7 & -4 & 2 & 8 & -7 & 1 & 10 & -11 & -1 & 14 & -14 & 0 \\
\hline \pm std. dev & 3 & 1 & 4 & 3 & 2 & 5 & 3 & 3 & 5 & 4 & 3 & 6 & 2 & 2 & 4 & 3 & 3 & 5 & 3 & 4 & 7 & 4 & 5 & 10 \\
\hline
\end{tabular}



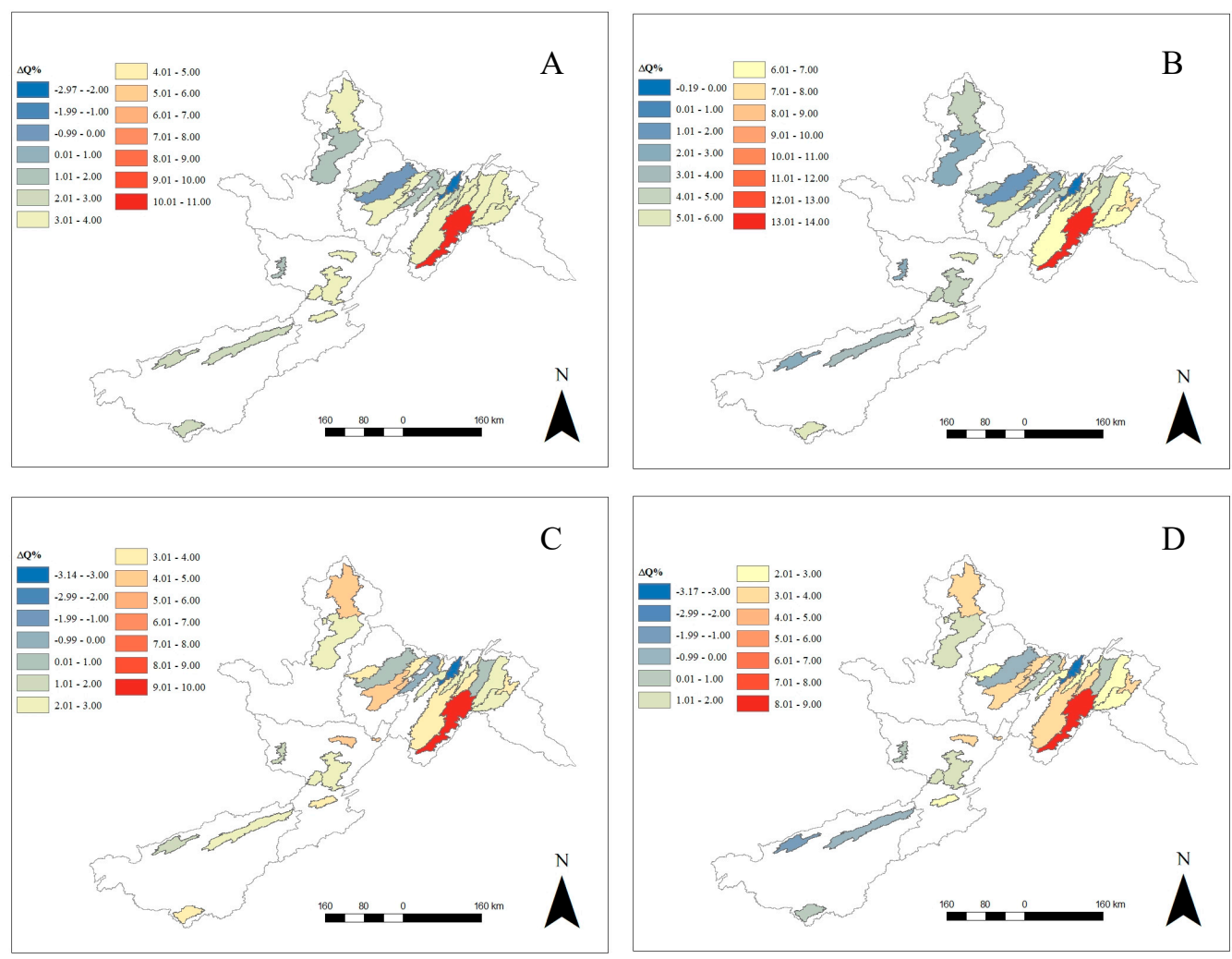

Figure 5. Changes in future streamflow for four future time periods based on RCP4.5 relative to the historic period (1950-2004). (A) 2005-2025; (B) 2026-2050; (C) 2051-2075; (D) 2076-2099.
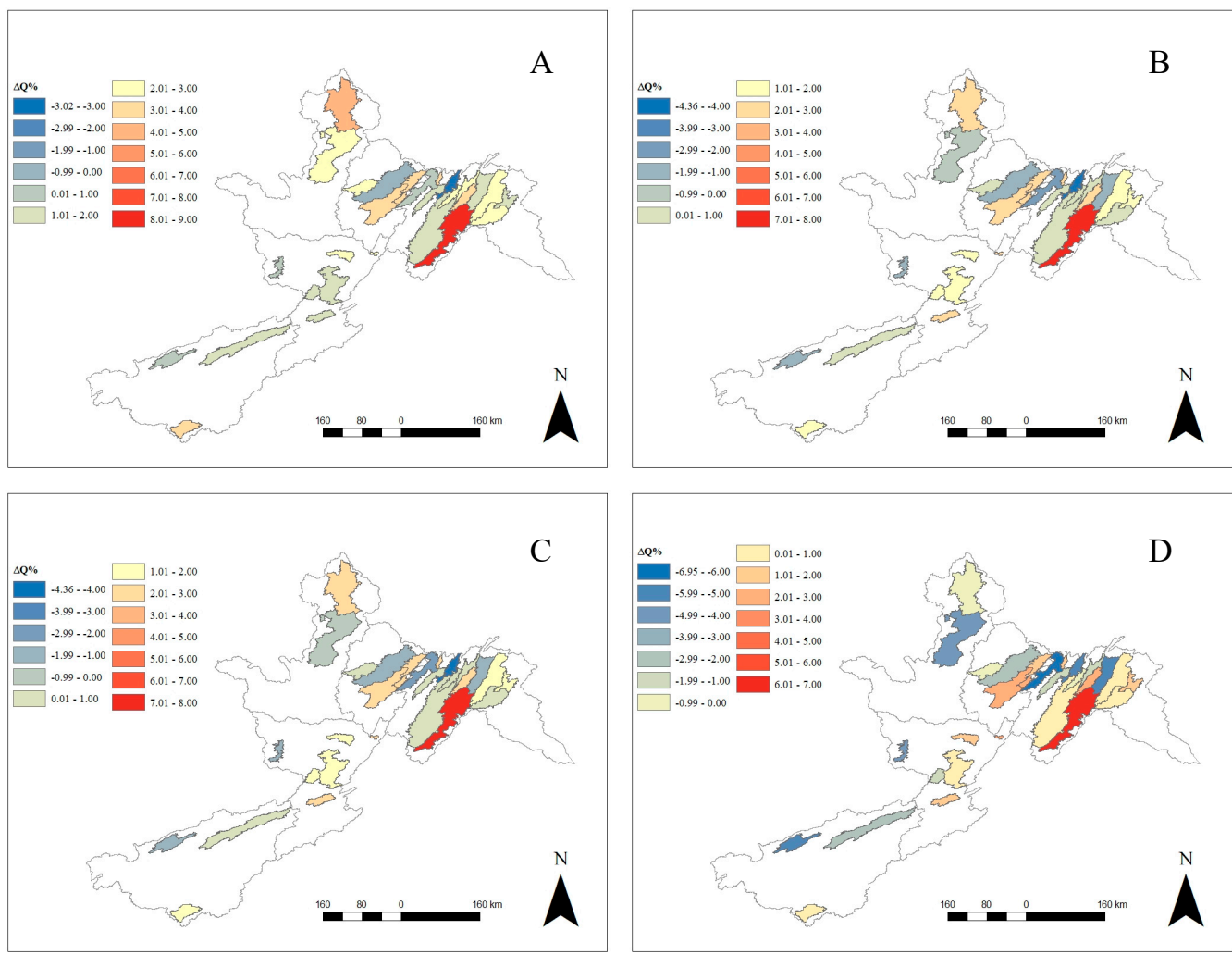

Figure 6. Changes in future streamflow for four future time periods based on RCP8.5 relative to the historic period (1950-2004). (A) 2005-2025; (B) 2026-2050; (C) 2051-2075; (D) 2076-2099. 
Streamflow changes attributed to changes in $\mathrm{P}\left(\Delta \mathrm{Q}_{\mathrm{P}}\right)$ were greater than changes attributed to $\operatorname{PET}\left(\Delta \mathrm{Q}_{\mathrm{PET}}\right)$ under RCP4.5 (Figure 5), but $\Delta \mathrm{Q}_{\mathrm{PET}}$ increased to comparable magnitudes of $\Delta \mathrm{Q}_{\mathrm{P}}$ late in the century under RCP8.5 (Table 4 and Figure 6). $\Delta \mathrm{Q}_{\mathrm{P}}$ increased by $1 \%-24 \%$ under RCP 4.5 and $2 \%-27 \%$ under RCP8.5, while $\triangle$ QPET increased by $2 \%-15 \%$ and $2 \%-28 \%$ for RCPs 4.5 and 8.5 , respectively (Figure 7).

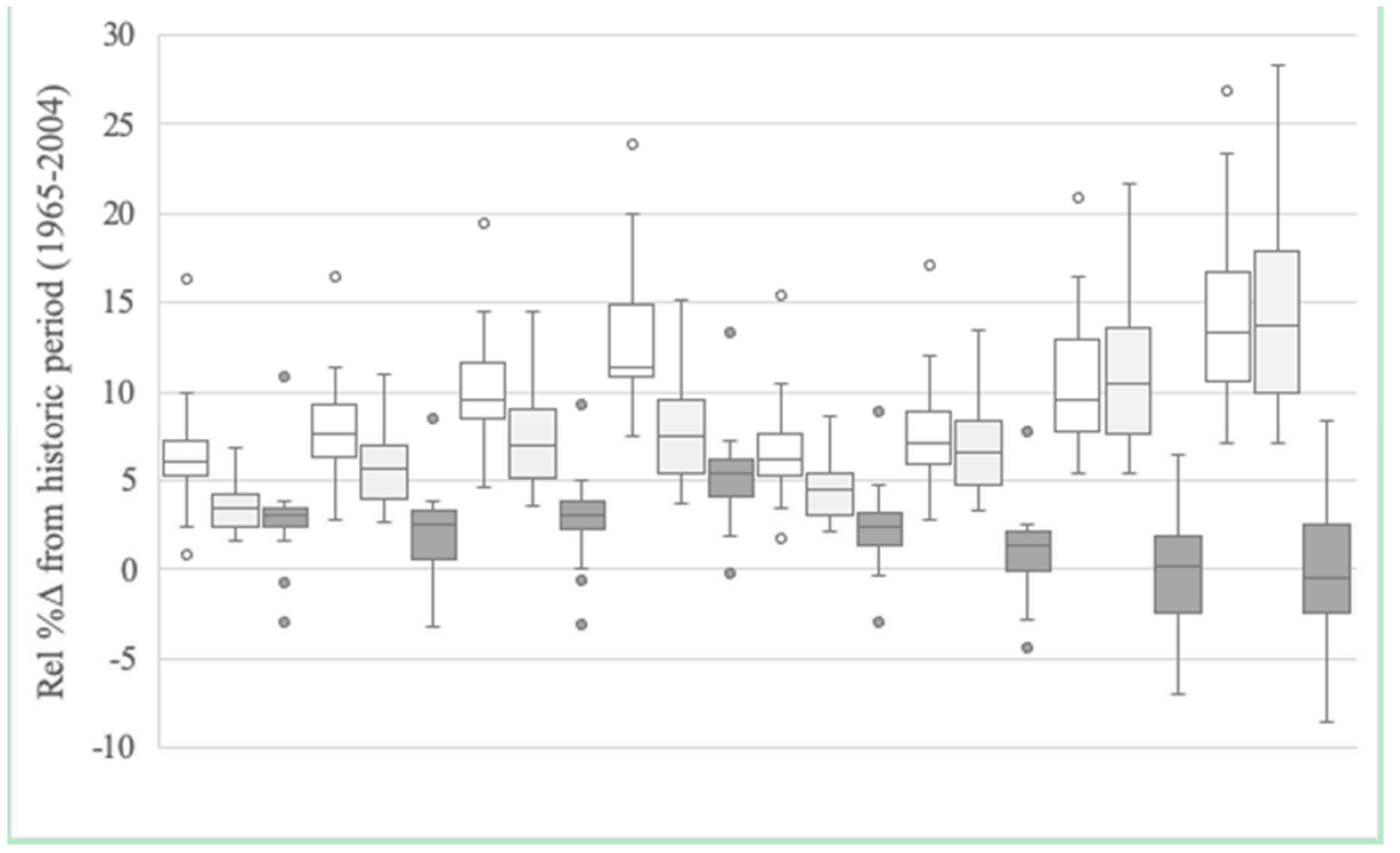

Figure 7. Box plots of future (2005-2099) changes in long-term annual streamflow $(\Delta Q)$ attributed to changes in precipitation $\left(\Delta \mathrm{Q}_{\mathrm{P}}\right)$ and potential evapotranspiration $\left(\Delta \mathrm{Q}_{\mathrm{PET}}\right)$ for RCP4.5 and RCP8.5. Streamflow changes are relative to the historical period (1950-2004).

\section{Discussion}

\subsection{Historic Climate, Water Balance Components, and Streamflow Sensitivity}

The catchment-scale $Q$ sensitivity to $P$ was greater than 1 and generally increased with increasing $\mathrm{E} / \mathrm{P}$, while the sensitivity of $\mathrm{Q}$ to PET was negative and the absolute value generally increased with increasing E/P (Figures 2 and 4). This implies that sensitivity to climate conditions was greater in arid catchments (those in the Potomac basin) than humid catchments (those in the Monongahela basin), which is consistent with other energy-limited regions [70,71]. The sensitivity to both $P$ and PET increases with increasing $\mathrm{n}$ value since the higher value of $\mathrm{n}$ generally corresponds to greater $\mathrm{E}$ for a given $\mathrm{P}$ and PET (Figure 2). The $\mathrm{n}$ value is a function of precipitation, topography, and slope $[47,65,72,73]$, indicating lower water availability in regions with higher $\mathrm{n}$ value.

The catchment sensitivities to both P and PET generally follow the continental divide of the Appalachian Mountains, which occurs between the Monongahela and Potomac where runoff moves to the Chesapeake Bay, due to rainfall partitioning properties occurring in the headwater region (Figures 3 and 4). Catchments situated closer to the divide (Monongahela, Kanawha, eastern Tennessee) tend to have lower sensitivity, except for the northern catchment in Ohio (1O), likely due to its proximity to the Great Lakes and therefore its lower PET. On the other hand, catchments east (leeward) of the divide tend to have greater sensitivity due to orographic lift, rainfall partitioning, and higher PET. Furthermore, high-elevation headwater catchments in the Monongahela, eastern Kanawha, and eastern Tennessee have lower sensitivity to P due to the low PET attributed to decreased temperatures and therefore lower aridity at high altitudes, which is consistent with other research conducted in the 
Appalachian Mountains [16]. Sensitivity to both P and PET increases with decreasing latitude, as PET rises due to increased dependence on sunshine hours and therefore radiation and temperature.

While $\mathrm{P}$, soil storage, and slope are important factors contributing to rainfall partitioning and $\mathrm{Q}$ sensitivity [65], landcover has important implications for rainfall partitioning in the region. Forests of the eastern US are highly dynamic $[68,74]$ due to natural (e.g., chestnut blight) and anthropogenic (e.g., forest succession, harvesting, industrialization) drivers. Furthermore, forests of the region are changing due to the rapid increase in unconventional gas development and legacy of surface coal mining throughout the region [75-77], which will likely increase regional streamflow ( $\Delta \mathrm{n} / \mathrm{n}$ in Table 1$)$.

Forest disturbances due to harvesting [78,79], coal mining [76,80], urbanization [81], unconventional gas development, and afforestation [74] alter the amount of $\mathrm{P}$ partitioned into $Q$. Deforestation generally increases $Q$ over the short-term by decreasing canopy interception and $\mathrm{E}$ [82], although the response of $\mathrm{Q}$ to forest removal also depends on the amount of water stored in a catchment [83]. As forests regrow, $Q$ can return to similar pre-disturbance levels [84], but because tree water use and canopy interception differ among species (e.g., [85,86]), post-disturbance forest composition can alter $Q$ over the long-term $[53,87]$. In the case of the forested catchments examined in this study, increases in deforestation will decrease $\mathrm{n}$ and $\mathrm{E}$ and increase $\mathrm{Q}$ (Table 1 ), while afforestation would show inverse relationships. Furthermore, forest disturbances over the 20th century have shifted the forest composition of the region from dominance by shade-intolerant and fire-adapted xerophytic species, which have adapted to live in areas with little water and low direct solar radiation (e.g., oaks (Quercus), chestnut (Castanea)), to shade-tolerant and fire-intolerant mesophytic species, which have adapted to variations in water content and high direct solar radiation (e.g., maple (Acer), cherry (Prunus)) [88]. Tree water use is generally higher for these species [85], which increases E and decreases $Q$ [89]. Furthermore, the tree water use and carbon dynamics of these species are also more sensitive to variations in climate $[86,90]$, and the sensitivity of $Q$ to climate change can increase with the increasing density of mesophytic species [87]. Changes in forest age, productivity, and succession [91], as well as changes in growing season length [26,30,32], are important factors for water balance partitioning. Therefore, increases in mesophication, forest productivity, and growing season length will increase $\mathrm{n}$ and $\mathrm{E}$ and subsequently decrease $\mathrm{Q}$.

\subsection{Twenty-First Century Climate and Streamflow}

Future climate changes projected for catchments in the central Appalachian Mountains region are consistent with other studies that show increases in both $\mathrm{P}$ and atmospheric water demand (e.g., [42,92,93]). Changes were greater in magnitude and variability with the more severe RCP compared to the more conservative pathway with lower atmospheric $\mathrm{CO}_{2}$ equivalents $[21,23,24]$. Early in the 21st century, relative changes in P and PET were similar in magnitude, but by the century's end under RCP8.5, increases in PET were projected to outpace P increases in all catchments. The larger increases in PET move the heavily forested catchments of the region towards greater aridity [16], potentially jeopardizing their role as reliable sources of freshwater to downstream communities $[2,89]$. The projection of $\mathrm{P}$ and PET represents some level of uncertainty due to the physics and resolution of the downscaled model. PET exhibits greater uncertainty than P for the region, which is likely due to its greater dependency on temperature and solar radiation [15]. Uncertainty increases in lower portions of the regions and in Q3 for RCP4.5 and Q4 for RCP8.5 due to the degree of change that occurs during these time periods [16].

Under RCP4.5, $\Delta \mathrm{Q}_{\mathrm{P}}$ values were consistently greater than $\Delta \mathrm{Q}_{\mathrm{PET}}$, with the net effect of increasing $\mathrm{Q}$ in 27 of 29 catchments for each future quarter period (Figure 5). Under RCP8.5, however, Q was more variable, decreasing by as much as $9 \%$ in quarter 4 for Patterson Creek and increasing by as much as $9 \%$ in the first quarter for Cedar Creek (both are located in the Potomac basin) (Figure 6). Across the region, $\mathrm{Q}$ was projected to increase in 28 of 29 catchments early in the century, but by the century's end, $Q$ was projected to decrease in more than half of the catchments, moving closer to the historic long-term regional average. In this case, the disproportionately large increases in PET offset 
potentially larger increases in $\mathrm{Q}$ due to $\Delta \mathrm{P}$ [43] (Figures 5 and 6). An important caveat of our work was that we assumed no changes in catchment properties in the future ( $\Delta \mathrm{n}=0$, Equation (9)); i.e., a transition from one steady state to another [35]. While quantifying future land use change and its role on $Q$ sensitivity was beyond the scope of this paper, it is important for managers and decision makers to consider disturbance and climate change together.

While our analysis suggests relatively moderate $Q$ changes throughout the 21 st century at the long-term annual scale, other studies show greater variability across the hydrologic regime. The largest increases in $P$ and $Q$ are projected to occur during winter and early spring [39,41,43], when atmospheric demand and forest water use are low [16], increasing the frequency of flooding [23]. P, on the other hand, is projected to decrease during summer when PET and human and ecosystem water use are high, which decreases summer flow [39]. Throughout the greater mid-Atlantic region that includes our study catchments, peak flow events with a $1 \%$ exceedance probability are projected to increase by between $10 \%-20 \%$, while low flows are projected to increase by as much as $14 \%[37,38,40]$.

\section{Conclusions}

Three clear patterns arise from our analysis on streamflow sensitivity to the changing climate in the central Appalachian region of the United States.

1. Catchments are more sensitive to $P$ than PET throughout the region and increased with increasing $\mathrm{E} / \mathrm{P}$, implying that arid catchments were more sensitive to change. Sensitivity also increased with increasing distance from the continental divide, with catchments on the leeward (eastern) side of the divide more sensitive to change. Furthermore, sensitivity increased with decreasing elevation and decreasing latitude due to greater dependence on temperature and radiation in those catchments.

2. Future $P$ and PET were greater in magnitude and variability with the more severe RCP (8.5). Early in the 21st century (2005-2025), changes in P and PET will remain consistent with each other; however, by 2099 under RCP 8.5, PET increases will outpace changes in P, which implies that business as usual $\mathrm{CO}_{2}$ emissions could trigger increased aridity in the region and threaten water resource sustainability.

3. Under RCP4.5, future $Q$ will increase in 27 of the 29 catchments for each future quarter period. However, under RCP 8.5, Q was more variable, especially in the catchments with high sensitivity in the Potomac basin. In the first half of the century (2005-2050), Q is projected to increase in 28/29 catchments, but by 2099, Q is projected to decrease in more than half of the catchments.

Our study contributes to the growing body of recent research that shows that anthropogenic climate change is altering freshwater provisioning throughout the region, posing considerable challenges for water resources management and water security. Floods, droughts, and low flow directly impact society through their immediate effects (e.g., pollution, inundation) and indirectly through ecosystem degradation, human health, work productivity, and the disruption of supply chains and the economy. Flooding poses significant risks to water quality and infrastructure. Increases in climate-driven droughts and low flows, due to the lack of precipitation or increase in atmospheric demand, degrades water quality and aquatic habitats by concentrating pollutants, increasing the costs of water treatment. As with much of the US, the central Appalachian region's roads, bridges, culverts, dams, and water treatment facilities are outdated, poorly maintained, and at a high risk of failure. Future changes in climate and streamflow will only increase the costs and damages to critical infrastructure. The changes in climate and hydrology found in this study suggest considerable challenges for managing the region's water quality, quantity, and security over the 21st century.

Author Contributions: Conceptualization, B.G., R.F., and N.Z.; Methodology, B.G. and R.F.; Formal Analysis, B.G. and N.Z.; Investigation, B.G. and N.Z.; Resources, N.Z.; Data Curation, R.F.; Writing-Original Draft Preparation, B.G. and N.Z.; Writing-Review \& Editing, N.Z.; Visualization, B.G. and N.Z.; Supervision, N.Z.; Project Administration, N.Z.; Funding Acquisition, N.Z. All authors have read and agreed to the published version of the manuscript. 
Funding: This research was funded by the National Science Foundation, grant number OIA-148952 and the USDA National Institute of Food and Agriculture Hatch project, grant number 1004360, both to Zegre. The dataset METDATA was produced by Northwestern University with funding from the NSF Idaho EPScoR Program, the National Science Foundation award number EPS-0814387, and the National Institute for Food and Agriculture competitive grant award 2011-68002-30191.

Conflicts of Interest: The authors declare no conflict of interest.

\section{References}

1. Creed, I.F.; Jones, J.A.; Archer, E.; Claassen, M.; Ellison, D.; McNulty, S.G.; van Noordwijk, M.; Vira, B.; Wei, X.; Bishop, K.; et al. Managing Forests for Both Downstream and Downwind Water. Front. For. Glob. Chang. 2019, 2. [CrossRef]

2. Duan, K.; Sun, G.; Caldwell, P.V.; McNulty, S.G.; Zhang, Y. Implications of Upstream Flow Availability for Watershed Surface Water Supply Across the Conterminous United States. JAWRA J. Am. Water Resour. Assoc. 2018, 54, 694-707. [CrossRef]

3. Dudley, N.; Stolton, S. Running Pure: The Importance of Forest Protected Areas to Drinking Water; World Bank/WWF Alliance for Forest Conservation and Sustainable Use: Gland, Switzerland; Washington, DC, USA, 2003.

4. Rodriguez-Iturbe, I.; Porporato, A. Ecohydrology of Water Controlled Ecosystems: Soil Moisture and Plant Dynamics; Cambridge University Press: Cambridge, UK, 2004.

5. Viviroli, D.; Dürr, H.H.; Messerli, B.; Meybeck, M.; Weingartner, R. Mountains of the world, water towers for humanity: Typology, mapping, and global significance. Water Resour. Res. 2007, 43. [CrossRef]

6. Viviroli, D.; Weingartner, R. The hydrological significance of mountains: from regional to global scale. Hydrol. Earth Syst. Sci. 2004, 8, 1017-1030. [CrossRef]

7. Marston, L.; Ao, Y.; Konar, M.; Mekonnen Mesfin, M.; Hoekstra Arjen, Y. High-Resolution Water Footprints of Production of the United States. Water Resour. Res. 2018, 54, 2288-2316. [CrossRef]

8. Hoekstra, A.Y.; Mekonnen, M.M. The water footprint of humanity. PNAS 2012, 109, 3232-3237. [CrossRef]

9. Rushforth, R.R.; Ruddell, B.L. A spatially detailed blue water footprint of the United States economy. Hydrol. Earth Syst. Sci. 2018, 22, 3007-3032. [CrossRef]

10. Brooks, R.P.; Limpisathian, P.W.; Gould, T.; Mazurczyk, T.; Sava, E.; Mitsch, W.J. Does the Ohio River Flow All the Way to New Orleans? JAWRA J. Am. Water Resour. Assoc. 2018, 54, 752-756. [CrossRef]

11. Bates, B.; Kundzewicz, Z.W.; Wu, S.; Palutikof, J. Climate Change and Water: Technical Paper vi; Intergovernmental Panel on Climate Change (IPCC): Geneva, Switzerland, 2008.

12. Vorosmarty, C.J.; Green, P.; Salisbury, J.; Lammers, R.B. Global Water Resources: Vulnerability from Climate Change and Population Growth. Science 2000, 289, 284-288. [CrossRef]

13. Döll, P.; Fiedler, K.; Zhang, J. Global-scale analysis of river flow alterations due to water withdrawals and reservoirs. Hydrol. Earth Syst. Sci. 2009, 13, 2413-2432. [CrossRef]

14. Budyko, M. Climate and Life; Academic: San Diego, CA, USA, 1974.

15. Guo, D.; Westra, S.; Maier, H.R. Sensitivity of potential evapotranspiration to changes in climate variables for different Australian climatic zones. Hydrol. Earth Syst. Sci. 2017, 21, 2107-2126. [CrossRef]

16. Fernandez, R.; Zegre, N. Seasonal Changes in Water and Energy Balances over the Appalachian Region and Beyond throughout the Twenty-First Century. J. Appl. Meteorol. Clim. 2019, 58, 1079-1102. [CrossRef]

17. Milly, P.C.D.; Dunne, K.A. Potential evapotranspiration and continental drying. Nat. Clim. Chang. 2016, 6, 946-949. [CrossRef]

18. Gudmundsson, L.; Greve, P.; Seneviratne, S.I. The sensitivity of water availability to changes in the aridity index and other factors-A probabilistic analysis in the Budyko space. Geophys. Res. Lett. 2016, 43, 6985-6994. [CrossRef]

19. Arora, V.K. The use of the aridity index to assess climate change effect on annual runoff. J. Hydrol. 2002, 265, 164-177. [CrossRef]

20. Huntington, T.G.; Richardson, A.D.; McGuire, K.J.; Hayhoe, K. Climate and hydrological changes in the northeastern United States: recent trends and implications for forested and aquatic ecosystemsThis article is one of a selection of papers from NE Forests 2100: A Synthesis of Climate Change Impacts on Forests of the Northeastern US and Eastern Canada. Can. J. For. Res. 2009, 39, 199-212. 
21. Hayhoe, K.; Wake, C.; Anderson, B.; Liang, X.-Z.; Maurer, E.; Zhu, J.; Bradbury, J.; DeGaetano, A.; Stoner, A.; Wuebbles, D. Regional climate change projections for the Northeast USA. Mitig. Adapt. Strateg. Glob. Chang. 2008, 13, 425-436. [CrossRef]

22. Huntington, T.G. Evidence for intensification of the global water cycle: Review and synthesis. J. Hydrol. 2006, 319, 83-95. [CrossRef]

23. Melillo, J.M.; Richmond, T.T.C.; Yohe, G. Chapter 16: Northeast; U.S. Global Change Research Program: Washington, DC, USA, 2014.

24. Pachauri, R.K.; Allen, M.R.; Minx, J.C. Climate Change 2014: Synthesis Report; Cambridge University Press: Cambridge, UK, 2014.

25. Walsh, K.J.E.; McBride, J.L.; Klotzbach, P.J.; Balachandran, S.; Camargo, S.J.; Holland, G.; Knutson, T.R.; Kossin, J.P.; Lee, T.-C.; Sobel, A.; et al. Tropical cyclones and climate change. Wiley Interdiscip. Rev. Clim. Chang. 2016, 7, 65-89. [CrossRef]

26. Kutta, E.; Hubbart, J. Climatic Trends of West Virginia: A Representative Appalachian Microcosm. Water 2019, 11, 1117. [CrossRef]

27. Douglas, E.M.; Vogel, R.M.; Kroll, C.N. Trends in floods and low flows in the United States: impact of spatial correlation. J. Hydrol. 2000, 240, 90-105. [CrossRef]

28. McCabe, G.J.; Wolock, D.M. A step increase in streamflow in the conterminous United States. Geophys. Res. Lett. 2002, 29, 2185. [CrossRef]

29. McCabe, G.J.; Wolock, D.M. Independent effects of temperature and precipitation on modeled runoff in the conterminous United States. Water Resour. Res. 2011, 47. [CrossRef]

30. Gaertner, B.A.; Zegre, N.; Warner, T.; Fernandez, R.; He, Y.; Merriam, E.R. Climate, forest growing season, and evapotranspiration changes in the central Appalachian Mountains, USA. Sci. Total. Environ. 2019, 650, 1371-1381. [CrossRef] [PubMed]

31. Hwang, T.; Band, L.E.; Miniat, C.F.; Song, C.; Bolstad, P.V.; Vose, J.M.; Love, J.P. Divergent phenological response to hydroclimate variability in forested mountain watersheds. Glob. Chang. Boil. 2014, 20, 2580-2595. [CrossRef] [PubMed]

32. Hwang, T.; Martin, K.L.; Vose, J.M.; Wear, D.; Miles, B.; Kim, Y.; Band, L.E. Nonstationary Hydrologic Behavior in Forested Watersheds Is Mediated by Climate-Induced Changes in Growing Season Length and Subsequent Vegetation Growth. Water Resour. Res. 2018, 54, 5359-5375. [CrossRef]

33. van Vuuren, D.P.; Edmonds, J.; Kainuma, M.; Riahi, K.; Thomson, A.; Hibbard, K.; Hurtt, G.C.; Kram, T.; Krey, V.; Lamarque, J.-F.; et al. The representative concentration pathways: an overview. Clim. Chang. 2011, 109, 5. [CrossRef]

34. Donohue, R.J.; Roderick, M.L.; McVicar, T.R. Roots, storms and soil pores: Incorporating key ecohydrological processes into Budyko's hydrological model. J. Hydrol. 2012, 436-437, 35-50. [CrossRef]

35. Roderick, M.L.; Farquhar, G.D. A simple framework for relating variations in runoff to variations in climatic conditions and catchment properties. Water Resour. Res. 2011, 47, W00G07. [CrossRef]

36. Devineni, N.; Lall, U.; Etienne, E.; Shi, D.; Xi, C. America's water risk: Current demand and climate variability. Geophys. Res. Lett. 2015, 42, 2285-2293. [CrossRef]

37. Baran, A.A.; Moglen, G.E.; Godrej, A.N. Quantifying Hydrological Impacts of Climate Change Uncertainties on a Watershed in Northern Virginia. J. Hydrol. Eng. 2019, 24, 05019030. [CrossRef]

38. Demaria, E.M.C.; Palmer, R.N.; Roundy, J.K. Regional climate change projections of streamflow characteristics in the Northeast and Midwest U.S. J. Hydrol. Reg. Stud. 2016, 5, 309-323. [CrossRef]

39. Stagge, J.H.; Moglen, G.E. Water Resources Adaptation to Climate and Demand Change in the Potomac River. J. Hydrol. Eng. 2017, 22, 04017050. [CrossRef]

40. Wu, S.-Y. Potential impact of climate change on flooding in the Upper Great Miami River Watershed, Ohio, USA: a simulation-based approach. Hydrol. Sci. J. 2010, 55, 1251-1263. [CrossRef]

41. Najjar, R.G.; Pyke, C.R.; Adams, M.B.; Breitburg, D.; Hershner, C.; Kemp, M.; Howarth, R.; Mulholland, M.R.; Paolisso, M.; Secor, D.; et al. Potential climate-change impacts on the Chesapeake Bay. Estuarine Coast. Shelf Sci. 2010, 86, 1-20. [CrossRef]

42. Hayhoe, K.; Wake, C.; Huntington, T.; Luo, L.; Schwartz, M.; Sheffield, J.; Wood, E.; Anderson, B.; Bradbury, J.; DeGaetano, A.; et al. Past and future changes in climate and hydrological indicators in the US Northeast. Clim. Dyn. 2007, 28, 381-407. [CrossRef] 
43. Hawkins, T.W.; Austin, B.J. Simulating streamflow and the effects of projected climate change on the Savage River, Maryland, USA. J. Water Clim. Chang. 2012, 3, 28-43. [CrossRef]

44. Lins, H.F. USGS Hydro-Climatic Data Network 2009 (HCDN-2009); U.S. Geologic Survey: Reston, VA, USA, 2012; 4p.

45. Slack, J.R.; Landwehr, J.M. Hydro-climatic Data Network (HCDN): A U.S. Geological Survey Streamflow Data Set for the United States for the Study of Climate Variations, 1874-1988; U.S. Geological Survey: Reston, VA, USA, 1998.

46. Wang, D.; Hejazi, M. Quantifying the relative contribution of the climate and direct human impacts on mean annual streamflow in the contiguous United States. Water Resour. Res. 2011, 47. [CrossRef]

47. Sankarasubramanian, A.; Vogel, R.M.; Limbrunner, J.F. Climate elasticity of streamflow in the United States. Water Resour. Res. 2001, 37, 1771-1781. [CrossRef]

48. Small, D.; Islam, S.; Vogel, R.M. Trends in precipitation and streamflow in the eastern US: Paradox or perception? Geophys. Res. Lett. 2006, 33. [CrossRef]

49. Krakauer, N.; Fung, I. Mapping and attribution of change in streamflow in the coterminous United States. Hydrol. Earth Syst. Sci. 2008, 12, 1111-1120. [CrossRef]

50. Luce, C.; Staab, B.; Kramer, M.; Wenger, S.; Isaak, D.; McConnell, C. Sensitivity of summer stream temperatures to climate variability in the Pacific Northwest. Water Resour. Res. 2014, 50, 3428-3443. [CrossRef]

51. Patterson, L.A.; Lutz, B.; Doyle, M.W. Climate and direct human contributions to changes in mean annual streamflow in the South Atlantic, USA. Water Resour. Res. 2013, 49, 7278-7291. [CrossRef]

52. Trewin, B.C. The Role of Climatological Normals in a Changing Climate; World Meteorological Organization: Geneva, Switzerland, 2007.

53. Jones, J.A.; Creed, I.F.; Hatcher, K.L.; Warren, R.J.; Adams, M.B.; Benson, M.H.; Boose, E.; Brown, W.A.; Campbell, J.L.; Covich, A.; et al. Ecosystem processes and human influences regulate streamflow response to climate change at long-term ecological research sites. BioScience 2012, 62, 390-404. [CrossRef]

54. Homer, C.; Dewitz, J.; Fry, J.; Coan, M.; Hossain, N.; Larson, C.; Herold, N.; McKerrow, A.; VanDriel, J.N.; Wickham, J. Completion of the 2001 national land cover database for the counterminous United States. Photogram. Eng. Remote Sens. 2007, 73, 337.

55. Abatzoglou, J.T. Development of gridded surface meteorological data for ecological applications and modelling. Int. J. Clim. 2013, 33, 121-131. [CrossRef]

56. Abatzoglou, J.T.; Brown, T.J. A comparison of statistical downscaling methods suited for wildfire applications. Int. J. Clim. 2012, 32, 772-780. [CrossRef]

57. Meinshausen, M.; Smith, S.J.; Calvin, K.; Daniel, J.S.; Kainuma, M.; Lamarque, J.-F.; Matsumoto, K.; Montzka, S.; Raper, S.; Riahi, K. The RCP greenhouse gas concentrations and their extensions from 1765 to 2300. Clim. Chang. 2011, 109, 213. [CrossRef]

58. Rocheta, E.; Sugiyanto, M.; Johnson, F.; Evans, J.; Sharma, A. How well do general circulation models represent low-frequency rainfall variability? Water Resour. Res. 2014, 50, 2108-2123. [CrossRef]

59. Tamaddun, K.A.; Kalra, A.; Kumar, S.; Ahmad, S. CMIP5 Models' Ability to Capture Observed Trends under the Influence of Shifts and Persistence: An In-Depth Study on the Colorado River Basin. J. Appl. Meteorol. Clim. 2019, 58, 1677-1688. [CrossRef]

60. Tamaddun, K.A.; Kalra, A.; Ahmad, S. Spatiotemporal Variation in the Continental US Streamflow in Association with Large-Scale Climate Signals Across Multiple Spectral Bands. Water Resour. Manag. 2019, 33, 1947-1968. [CrossRef]

61. Papadimitriou, L.V.; Koutroulis, A.G.; Grillakis, M.G.; Tsanis, I.K. The effect of GCM biases on global runoff simulations of a land surface model. Hydrol. Earth Syst. Sci. 2017, 21, 4379-4401. [CrossRef]

62. Mote, P.; Brekke, L.; Duffy, P.B.; Maurer, E. Guidelines for constructing climate scenarios. Eos Trans. Am. Geophys. Union 2011, 92, 257-258. [CrossRef]

63. Wang, X. Advances in separating effects of climate variability and human activity on stream discharge: An overview. Adv. Water Resour. 2014, 71, 209-218. [CrossRef]

64. Choudhury, B. Evaluation of an empirical equation for annual evaporation using field observations and results from a biophysical model. J. Hydrol. 1999, 216, 99-110. [CrossRef]

65. Padrón, R.S.; Gudmundsson, L.; Greve, P.; Seneviratne, S.I. Large-Scale Controls of the Surface Water Balance Over Land: Insights From a Systematic Review and Meta-Analysis. Water Resour. Res. 2017, 53, 9659-9678. [CrossRef] 
66. Budyko, M. Climate and Life, 508 pp; Academic Press: Cambridge, MA, USA, 1974; Volume 508, pp. $72-191$.

67. Li, L.J.; Zhang, L.; Wang, H.; Wang, J.; Yang, J.W.; Jiang, D.J.; Li, J.Y.; Qin, D.Y. Assessing the impact of climate variability and human activities on streamflow from the Wuding River basin in China. Hydrol. Process. 2007, 21, 3485-3491. [CrossRef]

68. Roman, D.; Novick, K.; Brzostek, E.; Dragoni, D.; Rahman, F.; Phillips, R. The role of isohydric and anisohydric species in determining ecosystem-scale response to severe drought. Oecologia 2015, 179, 641-654. [CrossRef]

69. Caldwell, P.V.; Miniat, C.F.; Elliott, K.J.; Swank, W.T.; Brantley, S.T.; Laseter, S.H. Declining water yield from forested mountain watersheds in response to climate change and forest mesophication. Glob. Chang. Boil. 2016, 22, 2997-3012. [CrossRef]

70. Sankarasubramanian, A.; Vogel, R.M. Hydroclimatology of the continental United States. Geophys. Res. Lett. 2003, 30. [CrossRef]

71. Gao, G.; Fu, B.; Wang, S.; Liang, W.; Jiang, X. Determining the hydrological responses to climate variability and land use/cover change in the Loess Plateau with the Budyko framework. Sci. Total. Environ. 2016, 557, 331-342. [CrossRef]

72. Milly, P.C.D. Climate, soil water storage, and the average annual water balance. Water Resour. Res. 1994, 30, 2143-2156. [CrossRef]

73. Cooper, M.G.; Schaperow, J.R.; Cooley, S.W.; Alam, S.; Smith, L.C.; Lettenmaier, D.P. Climate Elasticity of Low Flows in the Maritime Western U.S. Mountains. Water Resour. Res. 2018, 54, 5602-5619. [CrossRef]

74. Kutta, E.; Hubbart, J.A. Changing Climatic Averages and Variance: Implications for Mesophication at the Eastern Edge of North America's Eastern Deciduous Forest. Forests 2018, 9, 605. [CrossRef]

75. Drohan, P.J.; Brittingham, M.; Bishop, J.; Yoder, K. Early Trends in Landcover Change and Forest Fragmentation Due to Shale-Gas Development in Pennsylvania: A Potential Outcome for the Northcentral Appalachians. Environ. Manag. 2012, 49, 1061-1075. [CrossRef]

76. Miller, A.; Zégre, N. Landscape-Scale Disturbance: Insights into the Complexity of Catchment Hydrology in the Mountaintop Removal Mining Region of the Eastern United States. Land 2016, 5, 22. [CrossRef]

77. Sayler, K.L. Land Cover Trends: Central Appalachians. Available online: https://pubs.usgs.gov/ds/844/pdf/ ds844.pdf (accessed on 30 November 2019).

78. Kochenderfer, J.N.; Adams, M.B.; Miller, G.W.; Helvey, D.J. Factors affecting large peakflows on Appalachian watersheds: lessons from the Fernow Experimental Forest; U.S. Department of Agriculture, Forest Service, Northern Research Station: Newtown Square, PA, USA, 2007.

79. Kochenderfer, J.N.; Edwards, P.; Wood, F. Hydrologic Impacts of Logging an Appalachian Watershed Using West Virginia's Best Management Practices. North. J. Appl. For. 1997, 14, 207-218.

80. Messinger, T. Comparison of Storm Response of Streams in Small, Unmined and Valley-Filled Watersheds, 1999-2001, Ballard Fork, West Virginia; USGS: Reston, VA, USA, 2003.

81. Roy, A.H.; Dybas, A.L.; Fritz, K.M.; Lubbers, H.R. Urbanization affects the extent and hydrologic permanence of headwater streams in a midwestern US metropolitan area. J. North Am. Benthol. Soc. 2009, 28, 911-928. [CrossRef]

82. Bosch, J.M.; Hewlett, J.D. A review of catchment experiments to determine the effect of vegetation changes on water yield and evapotranspiration. J. Hydrol. 1982, 55, 3-23. [CrossRef]

83. Evaristo, J.; McDonnell, J.J. Global analysis of streamflow response to forest management. Nature 2019, 570, 455-461. [CrossRef]

84. Hornbeck, J.W.; Adams, M.B.; Corbett, E.S.; Verry, E.S.; Lynch, J.A. Long-term impacts of forest treatments on water yield: a summary for northeastern USA. J. Hydrol. 1993, 150, 323-344. [CrossRef]

85. Wullschleger, S.D.; Hanson, P.J.; Todd, D.E. Transpiration from a multi-species deciduous forest as estimated by xylem sap flow techniques. For. Ecol. Manag. 2001, 143, 205-213. [CrossRef]

86. Ford, C.R.; Laseter, S.H.; Swank, W.T.; Vose, J.M. Can forest management be used to sustain water-based ecosystem services in the face of climate change? Ecol. Appl. 2011, 21, 2049-2067. [CrossRef]

87. Young, D.; Zégre, N.; Edwards, P.; Fernandez, R. Assessing streamflow sensitivity of forested headwater catchments to disturbance and climate change in the central Appalachian Mountains region, USA. Sci. Total. Environ. 2019. [CrossRef]

88. Nowacki, G.J.; Abrams, M.D. The Demise of Fire and "Mesophication" of Forests in the Eastern United States. BioScience 2008, 58, 123-138. [CrossRef] 
89. Caldwell, P.; Muldoon, C.; Ford-Miniat, C.; Cohen, E.; Krieger, S.; Sun, G.; McNulty, S.; Bolstad, P.V. Quantifying the Role of National Forest System Lands in Providing Surface Drinking Water Supply for the Southern United States; U.S. Department of Agriculture Forest Service, Southern Research Station: Asheville, NC, USA, 2014.

90. Brzostek, E.R.; Dragoni, D.; Schmid, H.P.; Rahman, A.F.; Sims, D.; Wayson, C.A.; Johnson, D.J.; Phillips, R.P. Chronic water stress reduces tree growth and the carbon sink of deciduous hardwood forests. Glob. Chang. Boil. 2014, 20, 2531-2539. [CrossRef]

91. Schuler, T.M.; McGill, D.W. Long-Term Assessment of Financial Maturity, Diameter-Limit Selection in the Central Appalachians; USDA Forest Service: Washington, DC, USA, 2007; 16p.

92. Kang, H.; Sridhar, V. Assessment of Future Drought Conditions in the Chesapeake Bay Watershed. JAWRA J. Am. Water Resour. Assoc. 2018, 54, 160-183. [CrossRef]

93. Fernandez, R.; Sayama, T. Comparison of future runoff projections using Budyko framework and global hydrologic model: conceptual simplicity vs process complexity. Hydrol. Res. Lett. 2015, 9, 75-83. [CrossRef]

(C) 2020 by the authors. Licensee MDPI, Basel, Switzerland. This article is an open access article distributed under the terms and conditions of the Creative Commons Attribution (CC BY) license (http://creativecommons.org/licenses/by/4.0/). 